\title{
Potassium acts through mTOR to regulate its own secretion
}

\author{
Mads Vaarby Sørensen, ${ }^{1,2}$ Bidisha Saha, ${ }^{3}$ Iben Skov Jensen, ${ }^{1}$ Peng Wu, ${ }^{4}$ Niklas Ayasse, ${ }^{1}$ \\ Catherine E. Gleason, ${ }^{3}$ Samuel Levi Svendsen, ${ }^{1}$ Wen-Hui Wang, ${ }^{4}$ and David Pearce ${ }^{3}$ \\ 'Departments of Biomedicine and Physiology, Aarhus University, Aarhus, Denmark. ${ }^{2}$ Aarhus Institute for Advanced \\ Studies, Aarhus University, Aarhus, Denmark. ${ }^{3}$ Department of Medicine, Division of Nephrology, and Department of \\ Cellular and Molecular Pharmacology, UCSF, San Francisco, California, USA. ${ }^{4}$ Department of Pharmacology, New York \\ Medical College, Valhalla, New York, USA.
}

Potassium $\left(\mathrm{K}^{+}\right)$secretion by kidney tubule cells is central to electrolyte homeostasis in mammals. In the $\mathrm{K}^{+}$-secreting principal cells of the distal nephron, electrogenic $\mathrm{Na}^{+}$transport by the epithelial sodium channel $(\mathrm{ENaC})$ generates the electrical driving force for $\mathrm{K}^{+}$transport across the apical membrane. Regulation of this process is attributable in part to aldosterone, which stimulates the gene transcription of the ENaC-regulatory kinase, SCK1. However, a wide range of evidence supports the conclusion that an unidentified aldosterone-independent pathway exists. We show here that in principal cells, $\mathrm{K}^{+}$itself acts through the type 2 mTOR complex (mTORC2) to activate SGK1, which stimulates $\mathrm{ENaC}$ to enhance $\mathrm{K}^{+}$excretion. The effect depends on changes in $\mathrm{K}^{+}$concentration on the blood side of the cells, and requires basolateral membrane $\mathrm{K}^{+}$-channel activity. However, it does not depend on changes in aldosterone, or on enhanced distal delivery of $\mathrm{Na}^{+}$from upstream nephron segments. These data strongly support the idea that $\mathrm{K}^{+}$is sensed directly by principal cells to stimulate its own secretion by activating the mTORC2/SGK1 signaling module, and stimulate ENaC. We propose that this local effect acts in concert with aldosterone and increased $\mathrm{Na}^{+}$delivery from upstream nephron segments to sustain $\mathrm{K}^{+}$homeostasis.

Conflict of interest: The authors have declared that no conflict of interest exists.

Authorship note: MVS and BS contributed equally to this work

Copyright: (c) 2019 American Society for Clinical Investigation

Submitted: December 17, 2018

Accepted: April 17, 2019

Published: June 6, 2019.

Reference information: /CI Insight. 2019;4(11):e126910. https://doi. org/10.1172/jci.insight.126910

\section{Introduction}

In mammals, maintaining extracellular potassium ion concentration, $\left[\mathrm{K}^{+}\right]$, within a narrow range is essential for normal cell functions and the ability to sustain life (1). The problem of tight $\left[\mathrm{K}^{+}\right]$regulation is compounded by the fact that extracellular $\mathrm{K}^{+}$is a small fraction of total body $\mathrm{K}^{+}$, and hence $\left[\mathrm{K}^{+}\right]$could in principle be subject to large fluctuations, particularly in the face of a sudden increase in intake. Thus, mammals have developed efficient mechanisms to respond to changes in extracellular $\left[\mathrm{K}^{+}\right]$, substantially through rapid and profound changes in $\mathrm{K}^{+}$excretion by the kidneys. A combination of systemic (predominantly hormonal) and local renal signaling mechanisms have evolved to rapidly alter $\mathrm{K}^{+}$secretion into the kidney tubule lumen by principal cells (PCs) of the distal segment frequently referred to as the aldosterone-sensitive distal nephron (ASDN). The apical translocation of $\mathrm{K}^{+}$into the tubule lumen of PCs is mediated predominantly by the renal outer medullary $\mathrm{K}^{+}$channel (ROMK). The epithelial $\mathrm{Na}^{+}$ channel $(\mathrm{ENaC})$, which depolarizes the apical membrane, is central to establishing the driving force for $\mathrm{K}^{+}$movement $(1,2)$. Hormonal regulation of this process is predominantly by aldosterone, a steroid hormone, which acts through the mineralocorticoid receptor (MR) to regulate the transcription of multiple genes that control ENaC activity (3).

A key target of MR gene regulation is the serine-threonine kinase SGK1, which stimulates apical localization of $\mathrm{ENaC}$ and enhances electrogenic $\mathrm{Na}^{+}$reabsorption (4). The absence or inhibition of SGK1 activity results in $\mathrm{Na}^{+}$wasting and hyperkalemia in mice, despite markedly elevated aldosterone, which recapitulates many of the features of MR deficiency (5). To be activated, SGK1 must undergo phosphorylation within a short hydrophobic motif (HM) near its C-terminus, which is mediated by the kinase mTOR, specifically in its type 2 multiprotein complex, mTORC2 (6). The importance of mTORC2-dependent SGK1 phosphorylation in regulating $\mathrm{ENaC}$ activity and $\mathrm{K}^{+}$excretion is well established (7-9); however, the physiologically relevant control mechanisms have remained poorly characterized. 
Table 1. Urinary parameters in male NMRI and female C57BL/6 mice

\begin{tabular}{|c|c|c|c|c|c|c|c|c|}
\hline Mouse strain gavage treatment & $\begin{array}{l}\text { NMRI ctrl } \\
\text { vehicle }\end{array}$ & $\begin{array}{l}\text { NMRI ctrl } \\
\text { Benza }\end{array}$ & $\begin{array}{l}\text { NMRI KCI } \\
\text { vehicle }\end{array}$ & $\begin{array}{l}\text { NMRI KCI } \\
\text { Benza }\end{array}$ & $\begin{array}{l}\text { C57BL/6 ctrl } \\
\text { vehicle }\end{array}$ & $\begin{array}{l}\text { C57BL/6 ctrl } \\
\text { Benza }\end{array}$ & $\begin{array}{l}\text { C57BL/6 KCl } \\
\text { vehicle }\end{array}$ & $\begin{array}{c}\text { C57BL/6 KCI } \\
\text { Benza }\end{array}$ \\
\hline$n$ & 6 & 6 & 6 & 6 & 11 & 11 & 9 & 9 \\
\hline Sex & Male & Male & Male & Male & Female & Female & Female & Female \\
\hline Body mass (g) & $40.4 \pm 0.8$ & $39.5 \pm 2.4$ & $39.7 \pm 0.9$ & $40.0 \pm 1.1$ & $28.3 \pm 0.7$ & $28.6 \pm 1.0$ & $26.6 \pm 0.8$ & $23.3 \pm 0.7$ \\
\hline $\begin{array}{l}\text { Net } \mathrm{Na}^{+} \text {excretion } \\
(\mu \mathrm{mol} / \mathrm{g} \mathrm{BW} / 4 \mathrm{~h})\end{array}$ & $1.3 \pm 0.4$ & $3.0 \pm 0.6^{A}$ & $3.6 \pm 0.6 \$$ & $9.2 \pm 0.7^{A, B}$ & $1.6 \pm 0.3$ & $4.0 \pm 0.4^{A}$ & $4.8 \pm 0.4^{\mathrm{B}}$ & $10.9 \pm 1.4^{\mathrm{A}, \mathrm{B}}$ \\
\hline Urinary excretion $\mathrm{Na}^{+} / \mathrm{K}^{+}$ratio & $0.7 \pm 0.1$ & $20.2 \pm 5.3^{A}$ & $0.4 \pm 0.1$ & $4.9 \pm 0.6^{\mathrm{A}, \mathrm{B}}$ & $1.3 \pm 0.2$ & $12.7 \pm 2.9^{A}$ & $0.5 \pm 0.03^{B}$ & $3.4 \pm 1.0^{A, B}$ \\
\hline Net diuresis ( $\mu \mathrm{l} / \mathrm{g}$ BW/4 h) & $32 \pm 3$ & $38 \pm 2$ & $28 \pm 6$ & $34 \pm 8$ & $42 \pm 9$ & $26 \pm 9$ & $41 \pm 10$ & $35 \pm 6$ \\
\hline $\begin{array}{l}\text { Plasma [K+] } 1 \mathrm{~h} \text { after gavage } \\
(\mathrm{mM})\end{array}$ & $3.8 \pm 0.4$ & $4.1 \pm 0.5$ & $6.8 \pm 0.7^{\mathrm{B}}$ & $6.9 \pm 1.0^{\mathrm{B}}$ & $\mathrm{Na}$ & na & na & $\mathrm{Na}$ \\
\hline Plasma [aldosterone] (pg/ml) & $228 \pm 24$ & $309 \pm 46$ & $234 \pm 29$ & $299 \pm 52$ & $\mathrm{Na}$ & na & na & na \\
\hline
\end{tabular}

Mice were given either control or $\mathrm{KCl}$ gavage in combination with pretreatment of vehicle or benzamil (benza) injection. After gavage, mice were placed in metabolic balance cages for 4 hours with free access to water. Urine was collected, and urinary electrolytes and volume were measured. Data represent mean $\pm \mathrm{SEM}$; differences were determined by 1-way ANOVA. ${ }^{A} P<0.05$ versus benzamil treatment and respective vehicle control. ${ }^{B} P<0.05$ between control and $\mathrm{KCl}$ gavage with the same vehicle or benzamil treatment.

Additional genetic and physiological evidence also supports the idea that $\mathrm{K}^{+}$acts through non-aldosterone-dependent mechanisms to regulate $\mathrm{K}^{+}$excretion. Notably, even in the complete absence of aldosterone in mice (due to aldosterone synthase gene deletion), the $\mathrm{K}^{+}$excretory response to moderate changes in $\mathrm{K}^{+}$intake is near-normal (10). Similarly, dogs subjected to adrenalectomy and maintained on a low fixed level of aldosterone respond effectively to $\mathrm{KCl}$ infusion with increased $\mathrm{K}^{+}$excretion, which is further stimulated by exogenous aldosterone (11). One mechanism that contributes to this aldosterone-independent regulation is the local effect of $\left[\mathrm{K}^{+}\right]$to directly inhibit reabsorption of $\mathrm{Na}^{+}$and $\mathrm{Cl}^{-}$in the distal convoluted tubule of the kidney (12-14), a tubule segment just upstream of the ENaC-expressing ASDN. $\mathrm{Na}^{+}$and $\mathrm{Cl}^{-}$are reabsorbed together in an electroneutral fashion in this nephron segment by the sodium chloride cotransporter (NCC) (15). Its inhibition allows more $\mathrm{Na}^{+}$to pass to tubular segments further downstream where ENaC-mediated $\mathrm{Na}^{+}$reabsorption establishes the lumen negative potential driving $\mathrm{K}^{+}$secretion $(12,16,17)$. However, pharmacologic inhibition of NCC is insufficient to enhance $\mathrm{K}^{+}$excretion, despite a marked increase in $\mathrm{Na}^{+}$delivery to the $\operatorname{ASDN}(18,19)$; this stands in marked contrast to a $\mathrm{KCl}$ load, which rapidly stimulates both natriuresis and marked kaliuresis $(12,20)$.

Taken together, these observations suggested the hypothesis that an acute $\mathrm{K}^{+}$load acts to stimulate $\mathrm{ENaC}$ activity in PCs, and that this effect precedes and then is augmented by the ENaC-stimulatory effects of aldosterone. We further hypothesized that the mTORC2/SGK1 signaling module mediates these direct $\mathrm{K}^{+}$effects, and integrates them with those of aldosterone. Our present data, based on in vivo balance studies, kidney tubule patch-clamp experiments, and cell culture ion transport and kinase signaling studies support the idea that $\mathrm{K}^{+}$acts through basolateral membrane $\mathrm{K}^{+}$channels of PCs to stimulate apical membrane $\mathrm{ENaC}$ activity by enhancing mTORC2-mediated phosphorylation of SGK1. Our data further implicate WNK1 as an essential component of this signaling pathway, interestingly, independently of its kinase activity. We propose a model in which a WNK1/mTORC2/SGK1 signaling module integrates the effects of aldosterone with local effects of $\mathrm{K}^{+}$to regulate $\mathrm{K}^{+}$secretion and maintain $\mathrm{K}^{+}$homeostasis.

\section{Results}

$\mathrm{KCl}$ gavage or intravenous infusion acutely stimulates $\mathrm{ENaC}$-dependent $\mathrm{Na}^{+}$transport in mice. In order to assess the role of $\mathrm{ENaC}$ activity in the regulation of $\mathrm{K}^{+}$secretion in mice, we examined the effect of $\mathrm{K}^{+}$on $\mathrm{ENaC}$-mediated $\mathrm{Na}^{+}$reabsorption, using the highly specific ENaC inhibitor benzamil. The difference between $\mathrm{Na}^{+}$excretion in the presence and absence of intraperitoneal (i.p.) benzamil injection (benzamil-induced natriuresis [BIN]) has been widely used as a reflection of the amount of $\mathrm{Na}^{+}$that is being reabsorbed via $\mathrm{ENaC}(20,21)$. $\mathrm{K}^{+}$, administered by gavage, stimulates BIN in both male NMRI and female (C57BL/6) mice (data summarized in Table 1). In the male NMRI mice receiving a $\mathrm{K}^{+}$-free gavage, pretreatment with benzamil induced a 
A

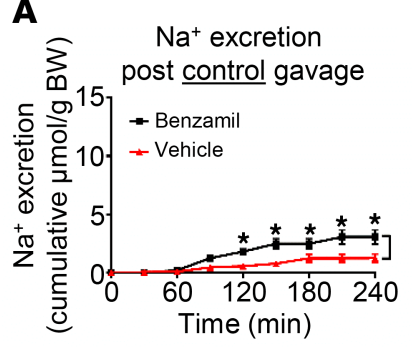

C

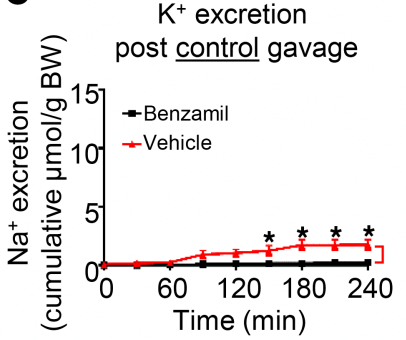

B

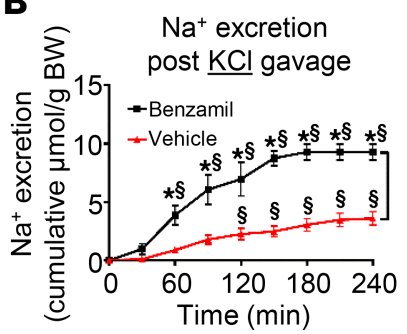

D

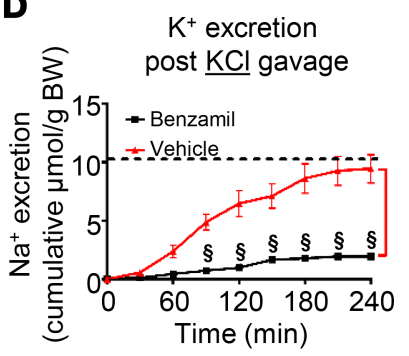

E

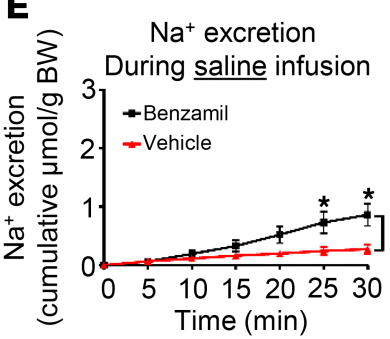

G

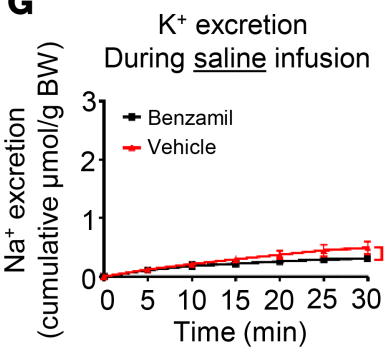

$\mathbf{F}$

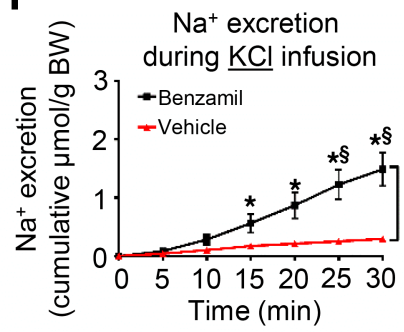

H

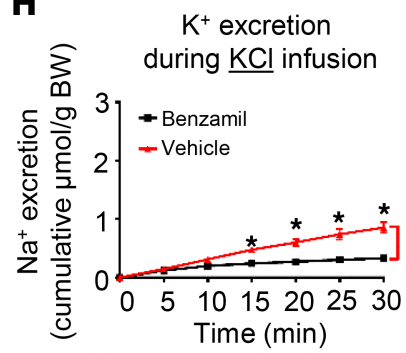

Figure 1. Systemic $\mathbf{K}^{+}$loading acutely increases benzamil-inducible urinary $\mathrm{Na}^{+}$loss. (A and $\mathbf{B}$ ) Cumulative $\mathrm{Na}^{+}$excretion relative to $\mathrm{BW}$ during 4 hours following control (A) or $\mathrm{KCl}(\mathbf{B})$ gavage in vehicle- versus benzamil-treated mice. Differences between the curves (marked with black bracket) represent benzamil-induced natriuresis (BIN). (C and D) Cumulative $\mathrm{K}^{+}$excretion relative to BW during the first 4 hours after control (C) or $\mathrm{KCI}$ (D) gavage in vehicle- versus benzamil-treated mice. Differences between the curves (marked with red bracket) represent benzamil-suppressible kaliuresis. Dashed line indicates $\mathrm{K}^{+}$load given. (E and $\mathbf{F}$ ) Cumulative $\mathrm{Na}^{+}$excretion during the first 30 minutes following intravenous saline control $(\mathbf{E})$ or $\mathrm{KCI}(\mathbf{F})$ infusion in vehicle- versus benzamil-treated mice. Differences between the curves (marked with black bracket) represent BIN. (G and $\mathbf{H}$ ) Cumulative $\mathrm{K}^{+}$excretion during the first 30 minutes following intravenous saline control (C) or $\mathrm{KCl}$ infusion $(\mathbf{H})$ in vehicle- versus benzamil-treated mice. Differences between the curves (marked with red bracket) represent benzamil-suppressible kaliuresis. In all panels, $(\boldsymbol{\Delta})$ represents vehicleand $(\mathbf{})$ represents benzamil-treated mice. ${ }^{*} P<0.05$ between vehicle and benzamil. ${ }^{\$} P<0.05$ between $\mathrm{KCl}$ and control loading by 2 -way ANOVA with Bonferroni's multiple-comparison test. $n=6$ in all presented data.

natriuresis of $1.8 \pm 0.4 \mu \mathrm{mol} \mathrm{Na} / \mathrm{g}$ BW over 4 hours (Figure $1 \mathrm{~A}$, difference between vehicle and benzamil curves). The BIN was approximately 3 -fold greater $(5.7 \pm 0.9 \mu \mathrm{mol} \mathrm{Na} / \mathrm{g}$ BW over 4 hours) in mice receiving $\mathrm{KCl}$ gavage $(10 \mu \mathrm{mol} \mathrm{K} / \mathrm{g} \mathrm{BW})$ (Figure $1 \mathrm{~B})$. The effect in spot urine collection was significant as early as 30-60 minutes after $\mathrm{K}^{+}$load (Figure 1B). A similar effect of $\mathrm{KCl}$ was observed in female C57BL/6 mice (Table 1). That this stimulatory effect of $\mathrm{KCl}$ on $\mathrm{ENaC}$ activity is linked to increased $\mathrm{K}^{+}$excretion can be seen as benzamil-suppressible kaliuresis. Consistent with earlier reports (22), $\mathrm{K}^{+}$excretion was stimulated 5 -fold by $\mathrm{KCl}$ gavage (from $1.8 \pm 0.4$ to $9.5 \pm 1.2$ ), and this effect was markedly reduced by benzamil (Figure $1, \mathrm{C}$ and $\mathrm{D}$, and Table 1). During this early-phase response, we did not detect a change in total ENaC subunit protein or $\alpha$ - and $\gamma$-ENaC cleavage products in the kidneys harvested 1 hour after gavage (Supplemental Figure 1; supplemental material available online with this article; https://doi.org/10.1172/jci.insight.126910DS1).

To investigate if the effect of $\mathrm{KCl}$ load relies on signals originating from the GI tract, and to better assess the kinetics, we infused $\mathrm{KCl}$ directly into tail veins of anesthetized mice with urine collected via bladder catheter. An acute shift of infusion from $\mathrm{NaCl}$ to $\mathrm{KCl}$ resulted in a significant 2-fold increase in BIN within 25 minutes, while $\mathrm{Na}^{+}$excretion in the vehicle-treated mice was not altered (compare benzamil- and vehicle-treated groups in Figure 1, E and F). As with the gavaged mice, intravenous infusion of $\mathrm{KCl}$ also induced kaliuresis, which was markedly suppressible by benzamil (Figure 1, G and $\mathrm{H}$ ).

$\mathrm{KCl}$-mediated increase of BIN is not a product of augmented $\mathrm{Na}^{+}$delivery to $\mathrm{ENaC}$. The above data support the conclusion that $\mathrm{KCl}$ gavage or infusion stimulates $\mathrm{ENaC}$ as reflected by increased BIN. Furthermore, this activation of ENaC is essential for enhancing $\mathrm{K}^{+}$excretion as reflected by the marked reduction in $\mathrm{K}^{+}$ excretion in benzamil-treated mice (Figure 1D). Previous work supports the conclusion that selectively increasing $\mathrm{Na}^{+}$delivery by inhibiting NCC with thiazides is not sufficient to enhance ENaC-dependent $\mathrm{K}^{+}$excretion (18), consistent with the idea that activation of ENaC per se is necessary. In order to further investigate the potential role of increased $\mathrm{Na}^{+}$delivery to the channel, we administered $\mathrm{NaCl}$ by gavage to induce natriuresis without inducing hypovolemia. Under these conditions, $\mathrm{NaCl}$ induced a marked natriuresis (significantly greater than that induced by $\mathrm{KCl}$ ) (Supplemental Figure 2); however, in sharp contrast 
A

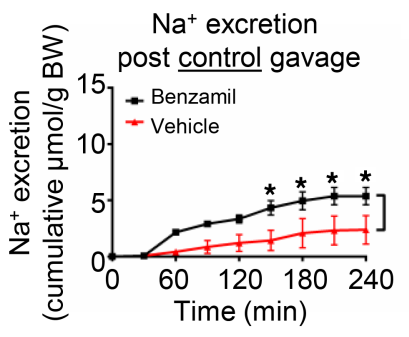

B

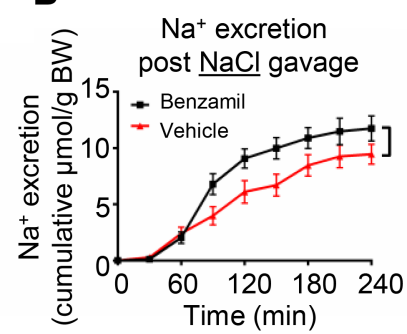

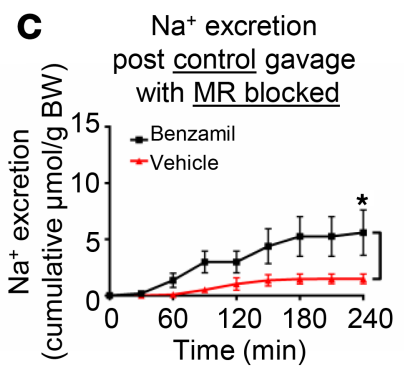

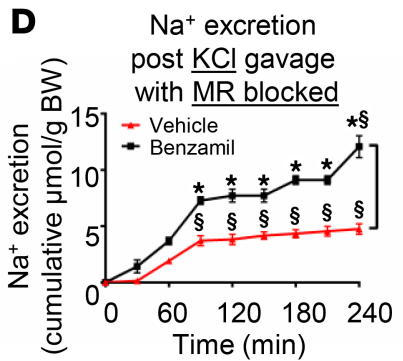

Figure 2. $\mathrm{K}^{+}$-stimulated benzamil-inducible urinary $\mathrm{Na}^{+}$loss is not due to increased $\mathrm{Na}^{+}$delivery to ENaC, and is largely independent of $\mathrm{MR}$ signaling. (A and B) Effect of control (A) or $\mathrm{NaCl}(\mathbf{B})$ gavage on $\mathrm{Na}^{+}$excretion in vehicle- versus benzamil-treated mice. (C and $\left.\mathbf{D}\right)$ Effect of control (C) or $\mathrm{KCl}(\mathbf{D})$ gavage on $\mathrm{Na}^{+}$excretion in vehicle- versus benzamil-treated mice in the presence of MR blockade by eplerenone. As in Figure 1, differences between curves (marked with black brackets) represent benzamil-induced natriuresis (BIN). In all panels, $(\boldsymbol{\Delta})$ represents vehicle- and $(\mathbf{\square})$ represents benzamil-treated mice. ${ }^{*} P<0.05$ between vehicle and benzamil. ${ }^{\$} P<0.05$ between control and $\mathrm{KCl}$ gavage by 2 -way ANOVA with Bonferroni's multiple-comparison test. $n=8$ in all presented data.

to $\mathrm{KCl}$ (Figure 1, A and B), it did not stimulate BIN (Figure 2, A and B). Thus, increased delivery of $\mathrm{Na}^{+}$ to $\mathrm{ENaC}$ does not by itself alter BIN.

Acute $\mathrm{KCl}$ stimulation of $\mathrm{ENaC}$ is $\mathrm{MR}$ independent. Together with prior literature, the above findings support the conclusion that $\mathrm{K}^{+}$-induced $\mathrm{K}^{+}$excretion requires ENaC stimulation. As noted above, it is well established that $\mathrm{K}^{+}$stimulates aldosterone secretion by the adrenal cortex, and that aldosterone acts in turn through the MR to stimulate $\mathrm{ENaC}$ (3). This effect is clearly important for long-term responses to large $\mathrm{K}^{+}$ loads; however, it may not be necessary for the early response to more physiological $\mathrm{K}^{+}$loads $(10,11)$. In support of the idea that the rapid activation of $\mathrm{ENaC}$ by $\mathrm{KCl}$ (Figure 1, B and $\mathrm{F}$ ) was not elicited by aldosterone, we found that plasma aldosterone levels in mice receiving control versus $\mathrm{KCl}$ were not significantly different 1 hour after gavage (Table 1). We then went on to directly assess the role of MR using the MR antagonist eplerenone. As shown in Figure 2, C and D, we found that $\mathrm{KCl}$ still stimulated BIN in mice pretreated with eplerenone (compare Figure 2, C and D). Indeed, the effect of $\mathrm{KCl}$ in mice treated with eplerenone was not significantly different from its effect in vehicle-treated controls (compare Figure 1, B and D).

Effect of extracellular $\left[\mathrm{K}^{+}\right]$on ENaC activity in native mouse $C C D$ and cultured $C C D$ cells. The above data strongly support the idea that $\mathrm{K}^{+}$can act independently of changes in aldosterone, $\mathrm{MR}$ activation, or signaling from the GI tract to rapidly modulate $\mathrm{ENaC}$ and regulate its own excretion. In order to begin to address the underlying mechanism, we next performed in vitro patch-clamp experiments on freshly isolated cortical collecting duct (CCD). Mouse CCD was dissected in normal $\mathrm{K}^{+}$buffer $(5 \mathrm{mM})$ as described previously (23), tubules were split open, and whole-cell patch conditions were established. After achieving a stable current at $-60 \mathrm{mV}$, extracellular $\left[\mathrm{K}^{+}\right]$was reduced to $1 \mathrm{mM}$ by replacing $4 \mathrm{mM}$ of the $\mathrm{KCl}$ with $\mathrm{NaCl}$, with all other buffer conditions unchanged. As shown in Figure $3 \mathrm{~A}$, reducing bath $\left[\mathrm{K}^{+}\right]$to $1 \mathrm{mM}$ resulted in a significant decrease in amiloride-sensitive current measured after approximately 15 minutes, consistent with the in vivo results.

We next examined the effect of changing $\left[\mathrm{K}^{+}\right]$in mpkCCD cells, a stable cell line that reproduces all of the key features of native CCD (24). In initial experiments, in order to achieve maximal distinction between low and high $\left[\mathrm{K}^{+}\right]$, we adapted the cells to DMEM containing $1 \mathrm{mM} \mathrm{KCl}$ and $144 \mathrm{mM} \mathrm{NaCl}$ without serum for 2 hours. At $t=0$, the medium was changed to the $\mathrm{K}^{+}$concentrations shown (Figure $3 \mathrm{~B}$ ), with inverse change of $\left[\mathrm{Na}^{+}\right]$to maintain constant osmolarity and total cation concentration. Consistent with both the in vivo balance studies and patch-clamp experiments, amiloride-sensitive current increased by $47 \%$ $\pm 0.27 \%$ when $\left[\mathrm{K}^{+}\right]$was increased to $3 \mathrm{mM}$ and by $88 \% \pm 1.58 \%$ when increased to $5 \mathrm{mM}$. Interestingly, there was no further increase in current when $\left[\mathrm{K}^{+}\right]$was increased to 6, 7 (Figure 3B), or $10 \mathrm{mM}$ (data not shown). Similar results were obtained when $\mathrm{K}^{+}$was replaced by choline chloride rather than $\mathrm{NaCl}$ (data not shown). An inverse effect was found when cells were adapted to $5 \mathrm{mM} \mathrm{K}^{+}$and shifted to $1 \mathrm{mM}$ (data not shown), consistent with the patch-clamp results in intact tubule.

In order to examine more physiologically relevant $\mathrm{K}^{+}$concentrations, comparable to those achieved in the in vivo experiments, we adapted the mpkCCD cells to $3 \mathrm{mM} \mathrm{K}^{+}$, and then added $\mathrm{KCl}$ to bring the $\left[\mathrm{K}^{+}\right]$up to $6 \mathrm{mM}$. As shown in Figure 3C, a significant increase in ENaC current was seen. The effects were less dramatic than 
A Native CCD

Amiloride-sensitive current
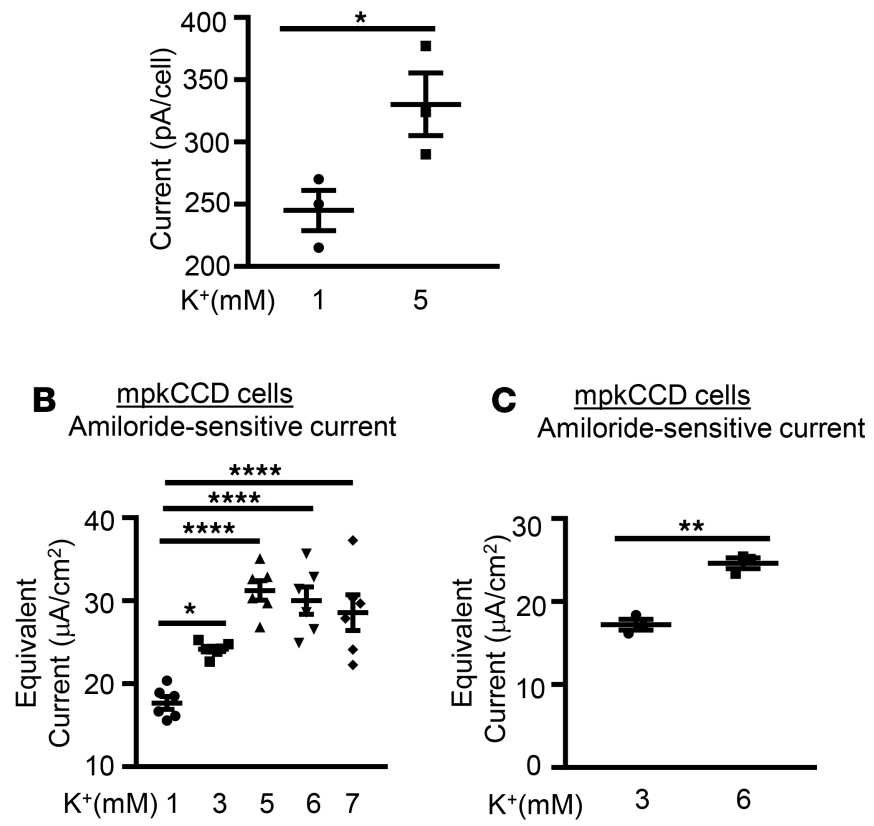

Figure 3. Extracellular [ $\left.\mathrm{K}^{+}\right]$regulates amiloride-sensitive $\mathrm{Na}^{+}$current. (A) $\mathrm{K}^{+}$regulates $\mathrm{ENaC}$ activity in native mouse CCD. Mouse collecting tubules were dissected in $5 \mathrm{mM} \mathrm{K}+$ buffer and subjected to apical membrane patch clamp. The bath $\left[\mathrm{K}^{+}\right]$was either changed to $1 \mathrm{mM}$ or maintained at $5 \mathrm{mM}$. ENaC current was assessed as amiloride-sensitive current at a clamp potential of $-60 \mathrm{mV} . n=5$ mice for each group. ${ }^{*} P<0.05$ by 2-tailed Student's $t$ test. pA, picoamperes. (B and C) $\mathrm{K}^{+}$stimulates $\mathrm{Na}^{+}$current in mpkCCD cells. Cells were adapted to $1 \mathrm{mM}\left[\mathrm{K}^{+}\right]$(B) or $3 \mathrm{mM}\left[\mathrm{K}^{+}\right](\mathbf{C})$ for 2 hours, medium $\left[\mathrm{K}^{+}\right]$was increased by addition of $\mathrm{KCl}$, and incubated for 1 hour additional prior to measurement of amiloride-sensitive current, as described in Methods. Data are mean \pm SEM from 3 independent experiments. ${ }^{*} P<0.05$; ${ }^{* * *} P<0.0001$ by 1 -way ANOVA (B). ${ }^{* *} P<0.01$ by 2 -tailed Student's $t$ test (C). $\mu \mathrm{A}$, microamperes.

those seen with larger changes in $\left[\mathrm{K}^{+}\right]$, but were consistent and highly statistically significant. Together, these data strongly support a direct local effect of $\mathrm{K}^{+}$to stimulate $\mathrm{ENaC}$ by increasing SGK1 activity in CCD cells.

$S G K 1$ activity is required for $\mathrm{K}^{+}$stimulation of $\mathrm{ENaC}$. Previous literature has established that SGK1 is an important regulator of $\mathrm{ENaC}$, and mediator of effects of aldosterone to stimulate $\mathrm{K}^{+}$excretion (25). SGK1 stimulates $\mathrm{ENaC}$ in a variety of experimental systems (25), and SGK1-KO mice fail to appropriately activate $\mathrm{ENaC}$ in response to increased dietary $\mathrm{K}^{+}$, and become hyperkalemic despite marked elevation of aldosterone (26). It is well established both in vitro and in vivo that $\mathrm{mTOR}$ is required for $\mathrm{ENaC}$ activity, and that its effects proceed at least in part through SGK1, which it phosphorylates within its C-terminal HM (7). Some activators of mTOR-dependent HM phosphorylation such as insulin and growth factors have been identified $(4,7)$; however, the role of regulated HM phosphorylation in physiological feedback mechanisms, particularly those that control extracellular $\left[\mathrm{K}^{+}\right]$, remains poorly characterized. With these considerations in mind, we first examined whether changing $\left[\mathrm{K}^{+}\right]$altered SGK1 HM phosphorylation. Immunoblots from the mpkCCD cells in Figure 3, B and C, were prepared and stained with anti-phospho-SGK1 S422. As shown in Figure 4, A and B, SGK1 S422 phosphorylation increased proportionately to the increase in amiloride-sensitive current (Figure 3, B and C, respectively), consistent with a role for SGK1 $\mathrm{HM}$ phosphorylation in $\mathrm{ENaC}$ stimulation by $\mathrm{K}^{+}$.

A role for SGK1 to stimulate $\mathrm{ENaC}$ in response to local changes in extracellular $\left[\mathrm{K}^{+}\right]$was further supported by the effects of SGK1 inhibition with GSK650394 (27), which blocked the increase in current induced by shifting media $\left[\mathrm{K}^{+}\right]$from $1 \mathrm{mM}$ to 5 or $8 \mathrm{mM}$ (Figure $4 \mathrm{C}$ ) and from $3 \mathrm{mM}$ to $6 \mathrm{mM}$ (Figure 4D).

mTORC2 activity is required for $\mathrm{K}^{+}$-stimulated SGK1 phosphorylation and activation of ENaC in native $C C D$ and cultured cells. We next asked if mTOR-dependent phosphorylation of SGK1 is required for $\mathrm{K}^{+}$-stimulated activation of $\mathrm{ENaC}$ by performing a series of inhibitor and knockout experiments in native tubules and cultured cells. We first performed patch-clamp experiments in native CCD treated with AZD8055, a potent and specific inhibitor of mTOR in both of its major complexes, mTORC1 
A mpkCCD cells

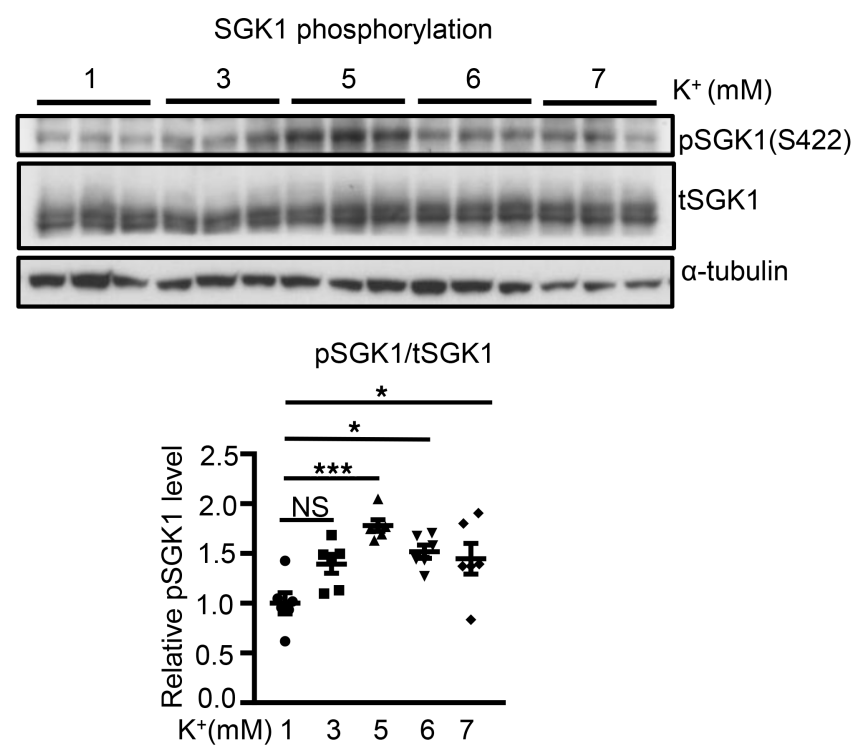

C mpkCCD cells

Amiloride-sensitive current

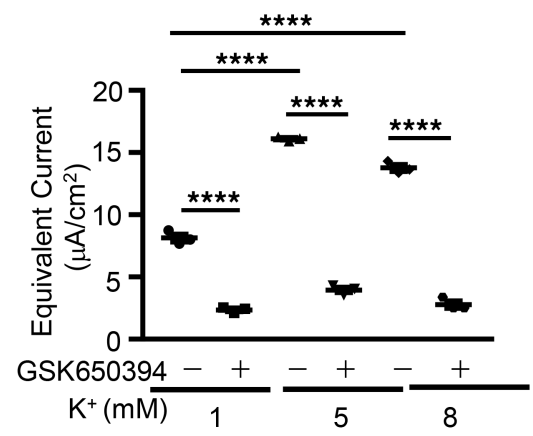

B mpkCCD cells

SGK1 phosphorylation

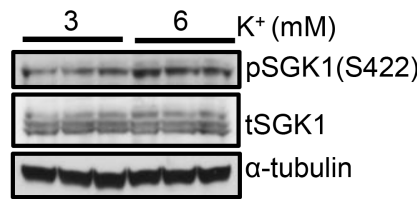

pSGK1/tSGK1

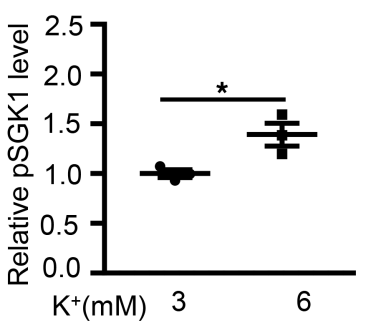

D $\underline{\text { mpkCCD cells }}$

Amiloride-sensitive current

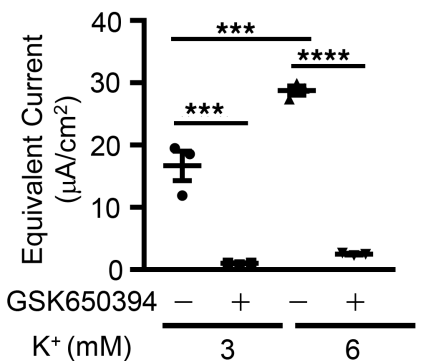

Figure 4. SCK1 activity is required for $\mathrm{K}^{+}$stimulation of ENaC. (A and $\left.\mathbf{B}\right) \mathrm{K}^{+}$stimulates SCK1 phosphorylation in mpkCCD cells. Cells from Figure 3, B and C, were lysed and prepared for Western blot, and stained with antibodies as indicated. Upper panels: Western blot images showing blots stained with anti-phospho-SGK1 S422, total SGK1, and $\alpha$-tubulin as labeled. Lower panels: Quantitation of phospho-SGK1/total SGK1 (as described in Methods). Data are mean \pm SEM from 3 independent experiments. ${ }^{*} P<0.05$, ${ }^{* *} P<0.001$ by 1-way ANOVA (A, lower panel). NS, not significant. ${ }^{*} P<0.05$ by 2-tailed Student's $t$ test (B, lower panel). (C and $\left.\mathbf{D}\right)$ Inhibition of SGK1 activity decreases $\mathrm{K}^{+}$-induced ENaC activity. mpkCCD cells were

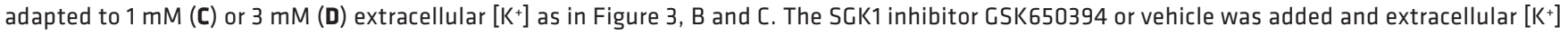
was then increased by addition of $\mathrm{KCl}$ for 1 hour prior to determining amiloride-sensitive $\mathrm{Na}^{+}$current. Data are mean $\pm \mathrm{SEM}$ from 3 independent experiments. ${ }^{* *} P<0.001,{ }^{* * *} P<0.0001$ by 1 -way ANOVA. $\mu \mathrm{A}$, microamperes.

and mTORC2. As shown in Figure 5A and Supplemental Table 1, AZD8055 suppressed current, as previously described (8), and abolished the difference in amiloride-sensitive current seen in 1 versus $5 \mathrm{mM} \mathrm{K}^{+}$. Similarly, in mpkCCD cells, AZD8055 blocked the ENaC-stimulatory effect of increasing $\left[\mathrm{K}^{+}\right]$from 1 to $5 \mathrm{mM}$ (Figure 5B), in parallel with blocking SGK1 S422 phosphorylation (Figure 5C). A chemically unrelated mTOR inhibitor, PP242 (7), had a similar effect (data not shown).

mTORC 1 and mTORC 2 both contain mTOR, but due to the specificity conferred by associated proteins such as Raptor (mTORC1), Rictor (mTORC2), and mSin1 (mTORC2), they respond to distinct stimuli and phosphorylate distinct targets (28). The bulk of data support the idea that under most conditions SGK1 is phosphorylated by mTORC2 $(6,7,29)$. However, there are data suggesting that in some cases SGK1 is phosphorylated by mTORC1 $(30,31)$. To address this issue in the context of $\mathrm{K}^{+}$regulation, we treated the mpkCCD cells with the mTORC1-specific inhibitor rapamycin, which had no effect on $\mathrm{K}^{+}$-induced current 
A Native $C C D$

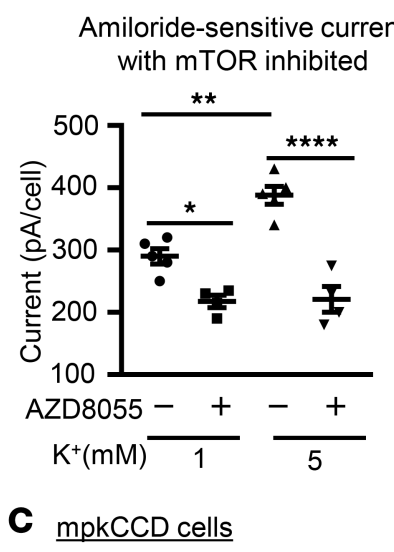

SGK1 phosphorylation with mTOR inhibited

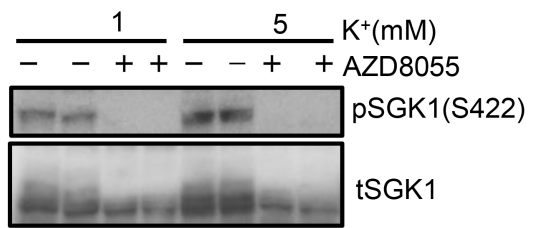

B $\quad$ mpkCCD cells

Amiloride-sensitive current with mTOR inhibited

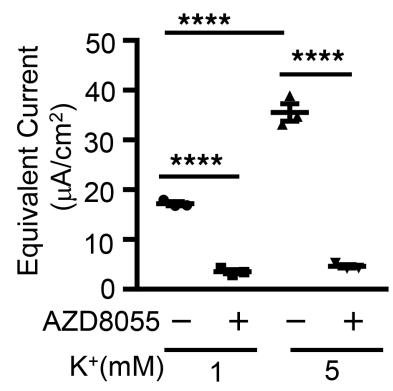

Figure 5. mTORC2 activity is required for the effects of extracellular [K+] on ENaC. (A) mTOR inhibition blocks $\mathrm{K}^{+}$-induced $\mathrm{ENaC}$ current in native CCD. Mouse collecting tubules were dissected in $5 \mathrm{mM}\left[\mathrm{K}^{+}\right]$buffer and subjected to apical membrane patch clamp, as in Figure 3A. The mTOR inhibitor AZD8055 was added, after which the bath $\left[\mathrm{K}^{+}\right]$was either changed to $1 \mathrm{mM}$ or maintained at $5 \mathrm{mM}\left[\mathrm{K}^{+}\right]$. Whole-cell measurements were made at a holding potential of $-60 \mathrm{mV} . n=5$ or 3 mice for each group as indicated in Supplemental Table $1 .{ }^{*} P<0.05,{ }^{*} P<0.01$, ${ }^{* * *} P<0.0001$ by 1 -way ANOVA: the differences are significant between 1 and $5 \mathrm{mM} \mathrm{K}{ }^{+}$and between AZD8055 treatments in comparison to their corresponding controls. pA, picoamperes. (B) mTOR inhibition blocks $\mathrm{K}^{+}$-induced ENaC current in mpkCCD cells. Cells were preincubated in $1 \mathrm{mM}\left[\mathrm{K}^{+}\right]$, as in Figure 3B. AZD8055 or vehicle was added as indicated, after which $\left[\mathrm{K}^{+}\right]$was shifted to $5 \mathrm{mM}$ where shown. Summary graph shown represents effect of AZD8055 on amiloride-sensitive $\mathrm{Na}^{+}$current. Data are mean \pm SEM from 3 independent experiments. ${ }^{* * *} P<$ 0.0001 by 1-way ANOVA. $\mu$ A, microamperes. (C) AZD8055 blocks SGK1 S422 phosphorylation in mpkCCD cells. Cells from Figure $5 B$ were lysed and prepared for Western blot, and stained with antibodies as indicated. Left panel: Western blot images showing blots stained with anti-phospho-SGK1 S422, and total SGK1 as labeled. Right panel: Quantitation of phospho-SGK1/total SGK1 (as described in Methods). Data are mean \pm SEM from 3 independent experiments. ${ }^{* *} P<0.01,{ }^{* * *} P<0.001,{ }^{* * *} P<0.0001$ by 1 -way ANOVA.

or SGK1 phosphorylation (data not shown). This result is consistent with the idea that the $\mathrm{K}^{+}$effect is mediated by mTORC2; however, the possibility remains that $\mathrm{mTORC} 1$ and $\mathrm{mTORC} 2$ are redundant in this regard, and both must be inhibited (as by AZD8055). In the absence of a specific pharmacologic inhibitor of mTORC2, we used the CRISPR-Cas9 system to knock out the mTORC2-specific component, mSin1 in HEK-293T cells, as described previously (32). We found that WT HEK-293T cells $\left(\mathrm{SIN}^{+/+}\right)$respond to an increase in extracellular $\left[\mathrm{K}^{+}\right]$with a robust increase in SGK1 phosphorylation (Supplemental Figure 3), which was lost in the mSin1-KO (HEK-293T SIN1 ${ }^{--}$) cells. Notably, phosphorylation of the mTORC1-specific target p70-S6 kinase was unaffected (data not shown; ref. 32). Transient transfection of $\mathrm{mSin} 1$ restored the effect of $\mathrm{K}^{+}$. In contrast, despite being mTORC2 dependent, phosphorylation of Akt (a close relative of SGK1) at S473 was unaffected by changes in $\left[\mathrm{K}^{+}\right]$(Supplemental Figure 3). Together with the native-tubule and mpkCCD data, these data strongly support the idea that $\mathrm{K}^{+}$acts locally within PCs to stimulate mTORC2-dependent SGK1 phosphorylation and thereby increase ENaC activity. Interestingly, this effect does not reflect generalized activation of mTORC2, but rather selective activity toward SGK1.

Effects of $\left[\mathrm{K}^{+}\right]$on $\mathrm{ENaC}$ are mediated by basolateral $\mathrm{K}^{+}$channels, most likely Kir4.1/5.1. The basolateral - but not the apical - membranes of PCs are exposed to $\mathrm{K}^{+}$concentrations that reflect plasma levels. 


\section{A mpkCCD cells}

Amiloride-sensitive current in response to change in apical $\left[\mathrm{K}^{+}\right]$
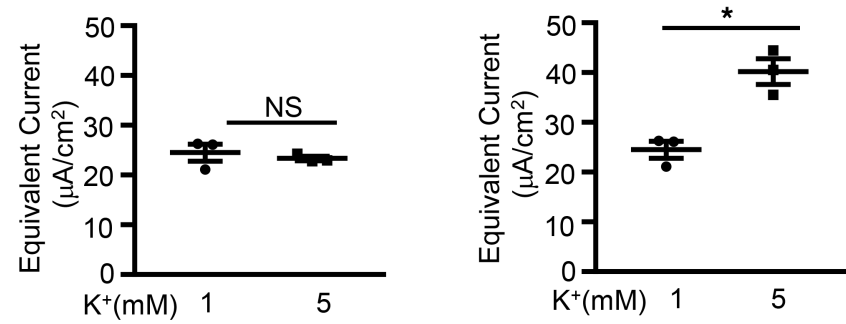

\section{B mpkCCD cells}

SGK1 phosphorylation in response to change in apical vs. basolateral $\left[\mathrm{K}^{+}\right]$

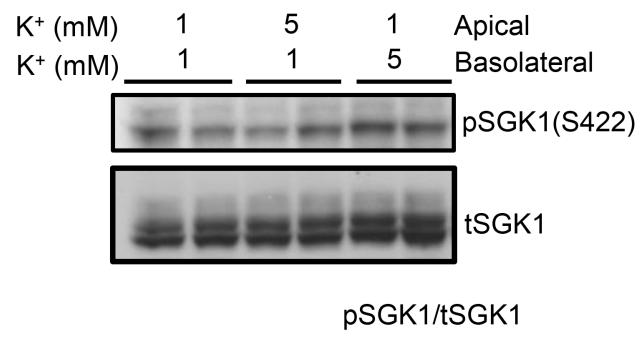

Change inapical $\left[\mathrm{K}^{+}\right]$
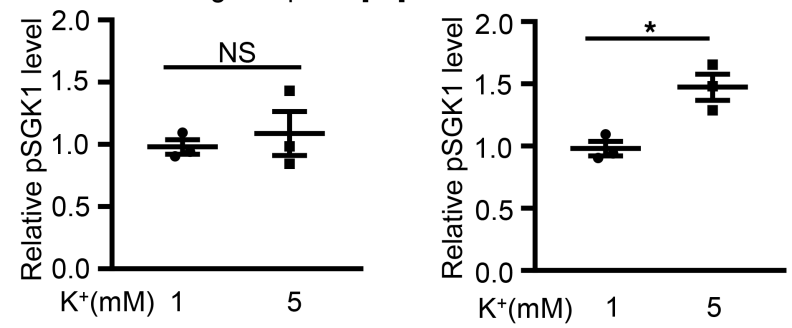

Figure 6. SGK1 phosphorylation and ENaC current are regulated by basolateral [ $\left.\mathbf{K}^{+}\right]$. (A) Effect on amiloride-sensitive current of changing apical (left panel) versus basolateral (right panel) [ $\left.\mathrm{K}^{+}\right]$from $1 \mathrm{mM}$ to $5 \mathrm{mM}$ in mpkCCD cells. Data are presented as mean \pm SEM. ${ }^{*} P<0.05$ by 2 -tailed Student's $t$ test. NS, not significant. (B) Effect on endogenous $p$-SGK1 S422 level of changing apical versus basolateral $\left[\mathrm{K}^{+}\right]$from $1 \mathrm{mM}$ to $5 \mathrm{mM}$. Upper panel: Western blot images showing blots stained with anti-phospho-SCK1 S422, and total SGK1 as labeled. Lower panels: Quantitation of phospho-SCK1/ total SCK1 in response to changes in apical (left panel) versus basolateral (right panel) [ $\left.\mathrm{K}^{+}\right]$(as described in Methods). Data are presented as mean $\pm \mathrm{SEM} .{ }^{*} P<0.05$ by 2 -tailed Student's $t$ test. Raising basolateral but not apical [K+] stimulates SGK1 S422 phosphorylation and $\mathrm{Na}^{+}$current.

Thus, a physiologically relevant effect on $\mathrm{ENaC}$ should be triggered by changing $\left[\mathrm{K}^{+}\right]$on the basolateral but not the apical side of the cells. We tested this by selectively altering basolateral versus apical $\left[\mathrm{K}^{+}\right]$in Transwells. As shown in Figure 6, in mpkCCD cells, ENaC current (Figure 6A) and SGK1 phosphorylation (Figure $6 \mathrm{~B}$ ) were stimulated by increasing basolateral but not apical $\left[\mathrm{K}^{+}\right]$, while an inverse effect was elicited by selectively decreasing basolateral $\left[\mathrm{K}^{+}\right]$(Supplemental Figure 4).

The resting potential of PC basolateral membranes is dominated by $\mathrm{K}^{+}$channels, predominantly, Kir4.1/5.1 (33). In order to determine if basolateral $\mathrm{K}^{+}$channels were implicated in the effects of $\left[\mathrm{K}^{+}\right]$, we treated mpkCCD cells adapted to $1 \mathrm{mM}\left[\mathrm{K}^{+}\right]$with $\mathrm{BaCl}_{2}$ on the basolateral side, just prior to changing $\left[\mathrm{K}^{+}\right]$, which was either raised to $5 \mathrm{mM}$ or kept at $1 \mathrm{mM}$ (Figure 7 , A and B). In cells maintained in $1 \mathrm{mM}$ $\mathrm{K}^{+}$, addition of $\mathrm{Ba}^{2+}$ stimulated amiloride-sensitive current (Figure 7A) and SGK1 phosphorylation (Figure 7B) comparably to raising $\left[\mathrm{K}^{+}\right]$to $5 \mathrm{mM}$. Ba ${ }^{2+}$ did not provide additional stimulation beyond that of $5 \mathrm{mM}$ $\left[\mathrm{K}^{+}\right]$, further supporting the conclusion that the effects of this signaling system plateau at $\mathrm{K}^{+}$concentrations in the high physiologic range. We further addressed the specific $\mathrm{K}^{+}$channel(s) by treating the cells with a 
A mpkCCD cells

Amiloride-sensitive current with basolateral $\mathrm{K}^{+}$channel inhibited

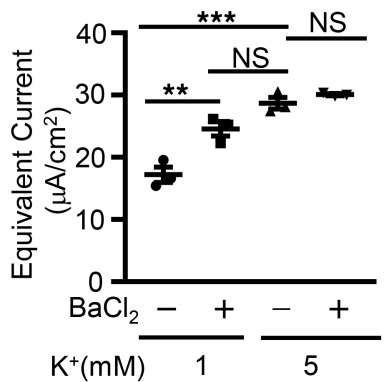

B mpkCCD cells
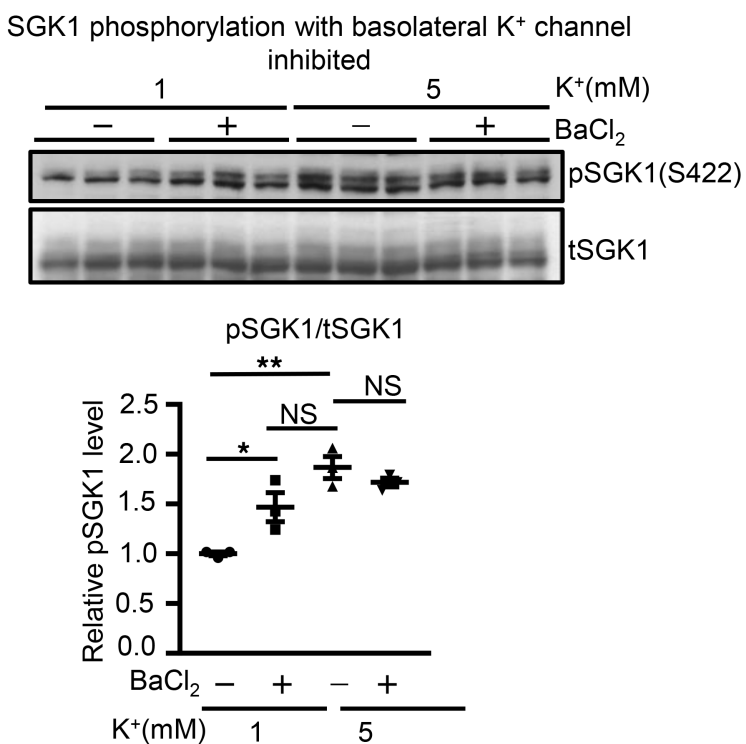

C mpkCCD cells

Amiloride-sensitive current with Kir4.1 inhibited

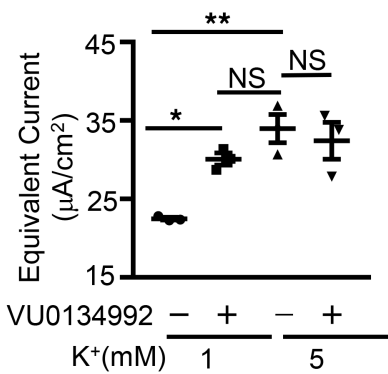

D mpkCCD cells

SGK1 phosphorylation with Kir4.1 inhibited

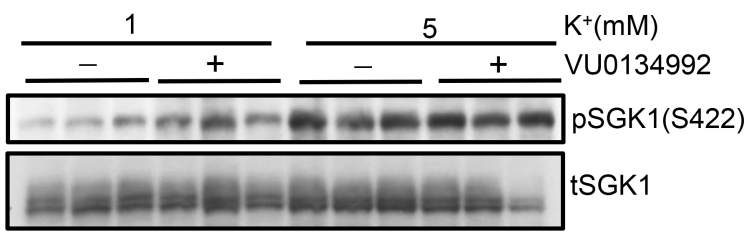

pSGK1/tSGK1

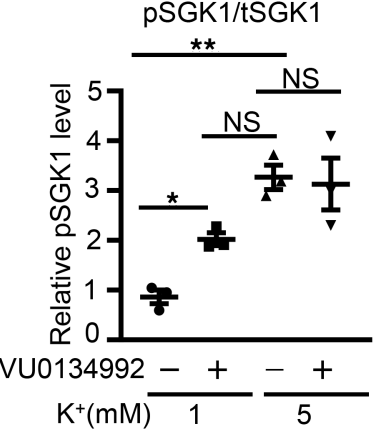

Figure 7. The effect of extracellular [ $\left.K^{+}\right]$on SGK1 phosphorylation and ENaC current is mediated by basolateral $\mathbf{K}^{+}$channels. (A and $B$ ) Effect of the $K^{+}-$channel inhibitor $\mathrm{Ba}^{2+}$ on $\mathrm{ENaC}$ current (A) and SGK1 phosphorylation (B). mpkCCD cells were adapted to $1 \mathrm{mM}\left[\mathrm{K}^{+}\right]$, and then [K+] was either raised to $5 \mathrm{mM}$ or kept at 1 $\mathrm{mM}$ for 1 hour. $\mathrm{BaCl}_{2}(100 \mu \mathrm{M})$ or vehicle was added to the basolateral medium 5 minutes before changing [K+]. Note in particular the ability of $\mathrm{Ba}^{2+}$ to increase $\mathrm{Na}^{+}$current and SCK1 phosphorylation in $1 \mathrm{mM}\left[\mathrm{K}^{+}\right]$to levels approaching those seen in $5 \mathrm{mM}\left[\mathrm{K}^{+}\right]$. Data are mean \pm SEM from 3 independent experiments. ${ }^{* *} P$ $<0.01,{ }^{* *} P<0.001$ by 1-way ANOVA. $\mu$ A, microamperes. (C and $\left.\mathbf{D}\right)$ Effect of the Kir4.1 inhibitor VU0134992 on ENaC current (C) and SGK1 phosphorylation (D). Cells were adapted to $1 \mathrm{mM}$ as in A and VU0134992 or vehicle was added to both basolateral and apical media 5 minutes before changing [K+]. Data are presented as mean \pm SEM. ${ }^{*} P=0.0036,{ }^{* *} P=0.001$ by multiple paired 2-tailed Student's $t$ test with Bonferroni's post hoc correction. NS, not significant.

newly developed inhibitor specific for Kir4.1, VU0134992 (ref. 34 and Figure 7, C and D). The effects found were similar to those of $\mathrm{Ba}^{2+}$, providing strong support for the idea that Kir4.1 (probably in the form of the heteromultimer Kir4.1/5.1) is part of a signaling system that mediates direct sensing of $\left[\mathrm{K}^{+}\right]$by the ASDN.

Potential role of WNK1 in linking changes of basolateral $\left[K^{+}\right]$to $S G K 1$ activation. The foregoing data support a mechanistic picture in which changes in basolateral $\left[\mathrm{K}^{+}\right]$alter the $\mathrm{K}^{+}$reversal potential, which results in altered membrane potential as $\mathrm{K}^{+}$moves through Kir4.1/5.1 channels. This somehow results in altered mTORC2-dependent phosphorylation of SGK1, with a concomitant change in ENaC activation by Nedd42. However, the mechanism by which a change in membrane potential alters mTORC2-dependent SGK1 phosphorylation is still unclear. In this context, the recently described effect of $\left[\mathrm{K}^{+}\right]$to alter WNK kinase activities in the distal convoluted tubule (DCT) might be relevant. WNKs are well known for their central role in a kinase cascade that proceeds through phosphorylation of the kinase SPAK, which in turn phosphorylates and activates NCC (35). Low $\left[\mathrm{K}^{+}\right]$stimulates — and high $\mathrm{K}^{+}$inhibits - this activity, at least in 
A $\mathrm{HEK}-293 \mathrm{~T}$ WNK1-1-

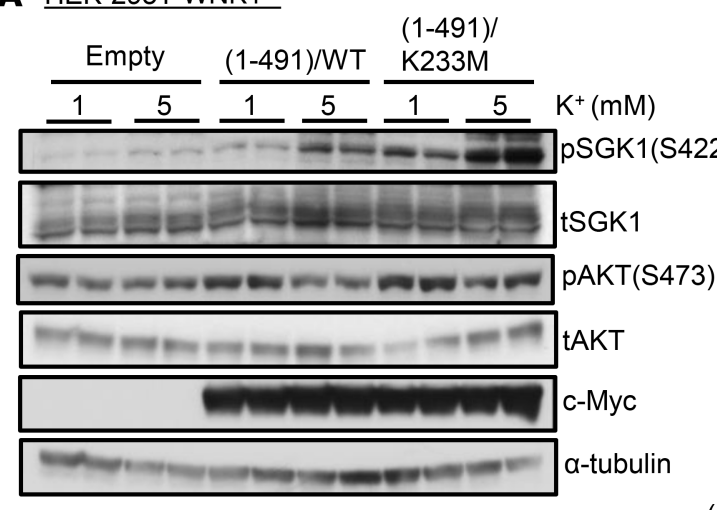

B

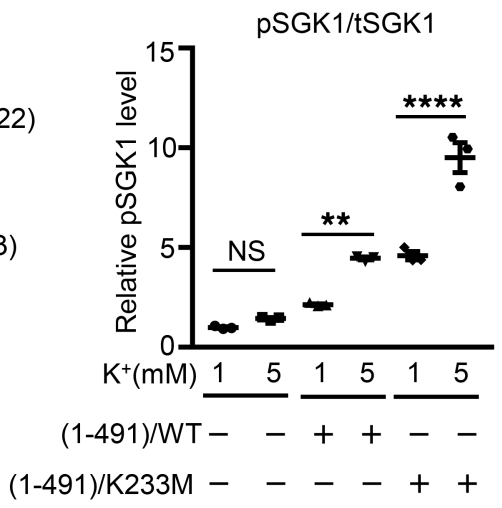

Figure 8. Role of WNK1 in extracellular [K+]-stimulated phosphorylation of SGK1. (A) Western blot analyses showing effects of WT (aa 1-491) versus kinase-dead WNK1 mutant (aa 1-491) (K233M) on extracellular [K+]-stimulated phosphorylation of SGK1. WNK1-deficient HEK-293 cells were transfected with FLAG-SGK1 and WNK1 (aa 1-491) WT or (aa 1-491) $\mathrm{K} 233 \mathrm{M}$. Cells were adapted to $1 \mathrm{mM}\left[\mathrm{K}^{+}\right]$, and then media $\left[\mathrm{K}^{+}\right]$was either raised to $5 \mathrm{mM}$ or kept at $1 \mathrm{mM}$ for 1 hour. In cells lacking WT or WNK1 K233M, raising extracellular [ $\left.\mathrm{K}^{+}\right]$to $5 \mathrm{mM}$ failed to stimulate SCK1 phosphorylation. Cells expressing K233M exhibited higher abundance of p-SCK1 compared with cells expressing WT WNK1. (B) Quantification of the Western blot data, presented as mean \pm SEM from 3 independent experiments. ${ }^{* *} P<0.01,{ }^{* * *} P<$ 0.0001 by 1 -way ANOVA. NS, not significant.

part by altering the intracellular concentration of $\mathrm{Cl}^{-}(14)$. WNK1 and WNK4 both bind $\mathrm{Cl}^{-}$, which inhibits their kinase activities (36). Other studies have suggested a role for WNKs in regulating $\mathrm{K}^{+}$secretion within the ASDN, which expresses high levels of WNK1, and moderate levels of WNK4 $(37,38)$.

As a first step toward assessing a potential role of WNKs in mediating the effects of $\left[\mathrm{K}^{+}\right]$on SGK1, we examined SGK1 phosphorylation in WNK1-deficient HEK-293T cells (HEK-293T WNK1 ${ }^{-/}$) (39). $\mathrm{K}^{+}$-stimulated SGK1 phosphorylation was nearly undetectable in these cells, and was fully rescued by heterologous WT or kinase-dead (K233M) WNK1 (residues 1-491) (Figure 8, A and B). In contrast, Akt phosphorylation (S473) (also mTORC2 dependent; Figure 8A and ref. 40) was unaffected by elimination of WNK1. Thus, the effect of WNK1 is not a generalized effect on mTORC2, but rather selectively modulates its activity toward SGK1. These findings are consistent with a role of WNK1 acting through a noncatalytic mechanism to modulate $\mathrm{K}^{+}$-regulated mTORC2-dependent SGK1 phosphorylation, as shown schematically in Figure 9.

\section{Discussion}

It is well established that mammals respond to an acute $\mathrm{K}^{+}$load with a profound and rapid increase in secretory $\mathrm{K}^{+}$excretion, which is mediated almost entirely by the distal segments of the renal tubules, and occurs through apical membrane $\mathrm{K}^{+}$channels (1). The driving force for apical $\mathrm{K}^{+}$movement is established by electrogenic $\mathrm{Na}^{+}$transport through $\mathrm{ENaC}(22)$. The steroid hormone aldosterone is essential for this process to proceed normally, particularly with chronic $\mathrm{K}^{+}$loading or when large quantities of $\mathrm{K}^{+}$must be excreted $(10,41)$. However, increasing evidence supports the idea that regulated $\mathrm{K}^{+}$secretion can occur to a significant extent independently of changes in aldosterone, particularly in response to the kind of $\mathrm{K}^{+}$load seen with a naturally occurring $\mathrm{K}^{+}$-rich meal $(10,11,42)$. Recent data support the idea that direct inhibition by $\mathrm{K}^{+}$of electroneutral $\mathrm{Na}^{+}-\mathrm{Cl}^{-}$cotransport via $\mathrm{NCC}$ contributes to $\mathrm{K}^{+}$secretion by enhancing $\mathrm{Na}^{+}$delivery to the $\mathrm{ENaC}$-expressing, $\mathrm{K}^{+}$-secretory segments $(12,14,16,43)$. However, NCC inhibition by itself is not sufficient for this rapid effect (18). Together, these observations suggest the hypothesis that $\mathrm{ENaC}$ might be acutely activated by local changes in $\left[\mathrm{K}^{+}\right]$.

Our present data strongly support the idea that $\mathrm{K}^{+}$is sensed and acts locally within PCs, independently of changes in aldosterone, to rapidly stimulate $\mathrm{ENaC}$ and thereby enhance its own secretion. First, we find in mice that a $\mathrm{K}^{+}$load begins to enhance benzamil-inducible $\mathrm{Na}^{+}$excretion (a reflection of $\mathrm{ENaC}$ activity) prior to significant change in aldosterone level, and that a substantial proportion of this early effect remains intact in the face of pharmacologic blockade of MR. This increase in ENaC activity also 


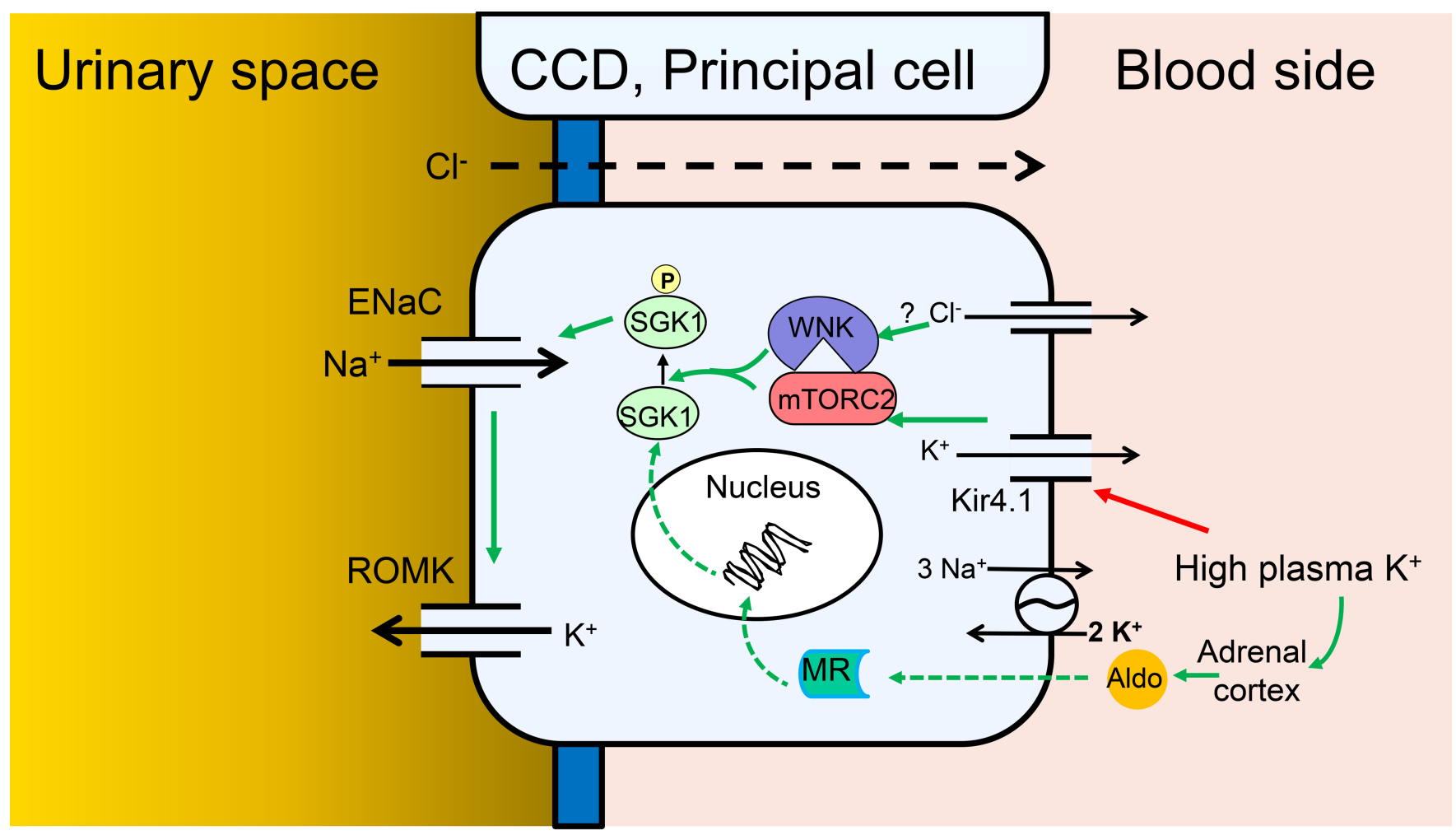

Figure 9. Model of $\mathrm{Na}^{+}$and $\mathbf{K}^{+}$transport regulation by local and systemic [ $\left.\mathbf{K}^{+}\right]$in PCs of the CCD. Cellular model of the integrated regulation of ENaC activity, and $\mathrm{ENaC}$-dependent $\mathrm{K}^{+}$secretion, in response to altered plasma $\mathrm{K}^{+}$. Green arrows indicate stimulatory effects. Red arrow indicates inhibitory effect. Solid arrows indicate rapid direct effects (seconds to minutes), dashed arrows indicate slower genomic effects (minutes to hours). According to this scheme, elevation of basolateral $\left[\mathrm{K}^{+}\right]$triggers membrane depolarization by altering the $\mathrm{K}^{+}$channel-dominated resting potential, which with a possible involvement of intracellular [ $\left.\mathrm{Cl}^{-}\right]$and WNK1 stimulates mTORC2-dependent SGK1 activation via $\mathrm{HM}$ phosphorylation. Activated SCK1 stimulates ENaC predominately by inhibiting Nedd4-2, but also potentially through other effects including ENaC phosphorylation. The ensuing increase in electrogenic Na+ transport enhances $\mathrm{K}^{+}$secretion via $\mathrm{K}^{+}$channels, predominantly renal outer medullary $\mathrm{K}^{+}(\mathrm{ROMK})$ channels, but also large-conductance $\mathrm{Ca}_{2}$-activated $\mathrm{K}^{+}$ (BK) channels. According to the model, SCK1 acts as a signal integrator, responding both to local signals that increase its activity, and to systemic hormonal signals (primarily aldosterone), which increase its expression.

is not due to increased $\mathrm{Na}^{+}$delivery to the channel, in that it is not duplicated by increasing $\mathrm{Na}^{+}$delivery through increased $\mathrm{Na}^{+}$load. Second, in patch-clamp experiments on isolated CCDs, selectively lowering $\left[\mathrm{K}^{+}\right]$inhibits ENaC activity. Third, in cultured CCD cells, raising basolateral $\left[\mathrm{K}^{+}\right]$in the culture medium rapidly stimulates - and lowering $\left[\mathrm{K}^{+}\right]$inhibits - amiloride-sensitive $\mathrm{Na}^{+}$current. That these acute effects on $\mathrm{ENaC}$ are implicated in controlling $\mathrm{K}^{+}$excretion in vivo is supported by the observation that benzamil inhibits $\mathrm{K}^{+}$excretion with a time course and extent that parallel its stimulation of $\mathrm{Na}^{+}$excretion (compare Figure 1, B and D), similar to prior reports (22).

As a first step toward characterizing the mechanism underlying this local regulation, we have shown in cultured CCD cells grown on Transwell filters that the effect is seen only with manipulation of basolateral (but not luminal) $\left[\mathrm{K}^{+}\right]$. We further observed that inhibition of basolateral $\mathrm{K}^{+}$channels with either the nonspecific $\mathrm{K}^{+}$-channel inhibitor, $\mathrm{Ba}^{2+}$, or with a specific inhibitor of Kir4.1 (VU0134992), mimics the effect of high $\left[\mathrm{K}^{+}\right]$, supporting the idea that Kir4.1-dependent basolateral membrane potential is integral to the underlying mechanism.

Our data further establish the central importance of the mTORC2/SGK1 signaling module in mediating these effects. SGK1 is a well-established ENaC regulator, which is under dual regulation; its gene expression is rapidly and potently stimulated by aldosterone, the biosynthesis of which is tightly regulated by $\left[\mathrm{K}^{+}\right]$. Aldosterone acts through MR to stimulate SGK1 gene transcription, and ultimately control its level of protein expression. However, SGK1 kinase activity requires mTORC2-dependent phosphorylation at S422 (within its C-terminal HM) (6), and acute inhibition of mTOR inhibits ENaC in both cultured cells (7) and in vivo (8). ENaC is stimulated substantially through the effect of SGK1 to phosphorylate and thus inhibit the ubiquitin ligase Nedd4-2 (44), although other effects of SGK1 to regulate ENaC may contribute: 
for example, direct phosphorylation of the channel (45). We find that $\mathrm{K}^{+}$stimulates mTORC2-dependent SGK1 phosphorylation, and that this effect is required for activation of ENaC. In addition to ENaC, it is also important to note that a role for regulation of $\mathrm{K}^{+}$channels themselves, in particular ROMK, cannot be ruled out (46). Indeed, one recent report found that genetic disruption of mTORC2 (via constitutive Rictor knockout) caused hyperkalemia by disrupting both ENaC and ROMK (9). Although this may play a role in chronic regulation, the bulk of evidence supports the idea that acute regulation proceeds predominantly through $\mathrm{ENaC}$-dependent control of the electrical gradient that drives $\mathrm{K}^{+}$secretion (22).

It is interesting to note the similarities and differences between our present findings and those of other groups focusing on $\mathrm{K}^{+}$effects in the DCT (47-49). In both cases, changing $\left[\mathrm{K}^{+}\right]$has cell-autonomous effects on apical transporters: ENaC on the one hand, NCC on the other. In both cases, the effect appears is to be induced by basolateral but not apical changes in $\left[\mathrm{K}^{+}\right]$, and to depend on basolateral $\mathrm{K}^{+}$ channels (possibly Kir4.1/5.1; ref. 50). However, in the 2 cases, the effects of $\mathrm{K}^{+}$are opposite: NCC is inhibited by high $\left[\mathrm{K}^{+}\right], \mathrm{ENaC}$ is stimulated. Both of these effects are physiologically rational; however, the mechanistic bases must diverge. WNK proteins play a well-established role to mediate $\mathrm{K}^{+}$-induced inhibition of NCC, while our present data suggest that WNK1 (and potentially WNK4) plays a key role in the effects of $\mathrm{K}^{+}$to selectively stimulate mTORC2 phosphorylation of SGK1 (Figure 8). In striking contrast to $\mathrm{K}^{+}$regulation of SPAK and $\mathrm{NCC}$, the $\mathrm{K}^{+}$effect on SGK1 phosphorylation does not require WNK1 kinase activity (Figure 8). Furthermore, the effect appears to be specific for SGK1, and not a generalized activation of mTORC2 because SGK1's close relative, Akt2 (also a substrate for mTORC2), is unaffected (Figure 8A and ref. 40). This latter observation is reminiscent of our recent findings that angiotensin II selectively stimulates SGK1 but not Akt phosphorylation (32). Of further interest, we found that changes in subcellular localization were central to this selective regulation; hormone-induced movement of mTORC2 and SGK1 from a perinuclear to plasma membrane location was required for selective regulation. With this in mind, it is notable that recent work from Boyd-Shiwarski et al. (51) demonstrated similar changes in WNK bodies in response to $\mathrm{K}^{+}$, in both DCT and connecting tubule cells. It will be of interest to explore these relationships in future work. Taken together with prior work from Cobb and colleagues (37), our present findings suggest that WNK1 serves as a $\mathrm{K}^{+}$-regulated scaffold that promotes mTORC2-dependent phosphorylation of SGK1, within the ENaC regulatory complex (52) (Figure 9). Although it is appealing to speculate that $\mathrm{Cl}^{-}$binding to WNK1 plays a role as it does in NCC regulation $(14,36)$, our current data are ambiguous. In any case, our present data suggest a parsimonious explanation for shifting $\mathrm{Na}^{+}$transport from electroneutral to electrogenic, particularly in DCT2 cells, which express both NCC and ENaC. Further experiments are needed to explore the role of $\mathrm{Cl}^{-}$and to characterize the precise mechanism of this WNK-mTORC2/SGK1 signaling module.

\section{Methods}

Please see supplemental material for additional details.

\section{Mice}

In vivo experiments performed in unanesthetized animals. We used male (NMRI) mice and as a control for gender- or strain-specific effects female (C57BL/6) mice. All mice were purchased from Janvier Labs. Mice were transported to Aarhus in a temperature-controlled $\left(21^{\circ} \mathrm{C}\right) \mathrm{car}$. Animals were acclimatized to the housing facility in Aarhus for at least 1 week before use in experiments. The mice were fed a control diet (ssniff EF R/M Control diet $\left(0.9 \% \mathrm{~K}^{+}\right.$and $\left.0.2 \% \mathrm{Na}^{+}\right)$(ssniff Spezialdiäten).

Infusion and native CCD patch-clamp experiments. Male C57BL/6 mice were used. The mice were fed a low-sodium diet for 10 days (TD90228, $0.01 \%-0.02 \% \mathrm{NaCl}$ ) prior to experiments.

All mice experienced a 12-hour light/12-hour dark cycle and had access to normal drinking water and a control diet ad libitum. All mice were 8 to 12 weeks of age at the time of the experiments. In order to prevent circadian aldosterone fluctuations from affecting our data, all animal experiments were started at 9 am.

\section{Electrolyte gavage}

Mice were either given a $\mathrm{K}^{+}, \mathrm{Na}^{+}$, or control gavage. To initiate a prandial metabolic response, i.e., rise in insulin, all gavages contained $2 \%_{\text {mass }}$ glucose. The $\mathrm{K}^{+}$gavage contained $2 \%_{\text {mass }} \mathrm{K}^{+}(512 \mathrm{mM})$ and $\mathrm{Cl}^{-}$. This maneuver is well described to increase plasma $\mathrm{K}^{+}$, reduce NCC phosphorylation, and induce natriuresis and kaliuresis acutely $(12,20)$. The $\mathrm{Na}^{+}$gavage had the same osmolarity $(512 \mathrm{mM})$ and $\mathrm{Cl}^{-}$concentration 
as the $\mathrm{K}^{+}$gavage. The control gavage only contained glucose. The mice received a volume of $20 \mu 1 / \mathrm{g} \mathrm{BW}$ and a total $\mathrm{K}^{+}$load that corresponds to approximately $25 \%$ of daily $\mathrm{K}^{+}$intake (53). Gavage was always given at 9 am and urine was collected as spot urine during the following 4 hours. During the 4-hour gavage experiments the mice only had access to water.

Benzamil injections. Benzamil is a specific ENaC antagonist (54). Benzamil (0.2 $\mu \mathrm{g} / \mathrm{g} \mathrm{BW} ; 0.4 \mathrm{mg} / \mathrm{ml}$ dissolved in $0.9 \%$ saline with $0.5 \% \mathrm{DMSO}$ ) or vehicle ( $5 \% \mathrm{DMSO}$ in $0.9 \%$ saline) was administrated via i.p. injections 15 minutes prior to gavage. This dose has been validated to inhibit ENaC efficiently and specifically (18).

\section{Spot urine in metabolic cages}

Before gavage, the mice were weighed to adjust electrolyte and benzamil dose. Post-gavage animals were placed in metabolic balance cages. Urine samples collected during handling of the mice prior to gavage were used as baseline values. Urine samples were collected as spot urine, as previously described (20).

\section{$\mathrm{KCl}$ infusion}

Mice were given a single water load $(25 \mu \mathrm{l} / \mathrm{g}$ BW) as gastric gavage and then anesthetized with an i.p. injection of ketamine and xylazine. Anesthesia was maintained by repetitive bolus injection with a third of the induction dose every 30 minutes. While the mice were placed on a thermostatic controlled heating plate $\left(38^{\circ} \mathrm{C}\right)$ an intravenous catheter was inserted in a tail vein and continuous infusion of $300 \mathrm{mOsm}$ saline was started. The lower part of the abdomen was then incised, and the urinary bladder was identified and cath eterized. Urine was collected every 5 minutes for flame photometry. The mice were randomly divided in 2 groups. In one group the saline infusion was switched to $300 \mathrm{mOsm} \mathrm{KCl}$ after the first 30 minutes at a rate of $4 \mu \mathrm{l} / \mathrm{g} \mathrm{BW} / \mathrm{h}$. The infusion rate was titrated to reach $\left[\mathrm{K}^{+}\right]_{\mathrm{p}}$ of approximately $6 \mathrm{mM}$. In the second group the saline infusion was continued throughout the experiment. Simultaneously with changes of infusate, all animals received an i.p. bolus injection of benzamil or vehicle.

\section{MR blockade}

Eplerenone is a specific MR antagonist with relatively long half-life in vivo (55). Eplerenone tablets (Teva Pharma) were dissolved in tap water $(20 \mathrm{mg}$ eplerenone $/ \mathrm{ml})$ and administrated by gavage. Mice were given $200 \mu \mathrm{g} / \mathrm{g}$ BW daily (divided into 2 doses of $100 \mu \mathrm{g} / \mathrm{g} \mathrm{BW}$ at 9:00 am and 9:00 pm) for 4 days prior to experiments and $100 \mu \mathrm{g} / \mathrm{g} \mathrm{BW}$ at 9:00 am on the day of the experiments. Efficacy of the MR blockade using this protocol has previously been verified in our laboratory (53).

\section{Flame photometry}

The concentrations of $\mathrm{Na}^{+}$and $\mathrm{K}^{+}$in the urine samples were measured using a flame photometer (Model 420 Flame Photometer, Sherwood Scientific) on a 3-mM LiCl background. In order for the samples to be in the detection range, the samples were diluted $1: 4$ in $\mathrm{ddH}_{2} \mathrm{O}$.

\section{Plasma electrolyte and aldosterone measurements and tissue harvest}

Forty-five minutes after gavage, mice were anesthetized using ketamine and xylazine i.p. injections. One hour after gavage, blood was sampled by retroorbital puncture using a heparinized capillary tube. Blood was analyzed immediately in an blood gas and osmolyte analyzer. Subsequently, whole blood was extracted from the right atrium of the heart by a heparinized syringe and centrifuged at 4,600 $\mathrm{g}$ for 2 minutes. The plasma was kept at $-80^{\circ} \mathrm{C}$. Plasma aldosterone was measured using an ELISA kit.

After blood collection, mice were perfused with $20 \mathrm{ml}$ PBS via the left atrium of the heart. The kidneys were then removed, decapsulated, and then snap-frozen in liquid nitrogen and kept at $-80^{\circ} \mathrm{C}$ until use.

\section{Patch-clamp and whole-cell current measurement in native CCD}

The collecting tubules were dissected from the kidney slices, split open, and prepared for apical membrane patch clamp, as previously described (56). An Axon 200A amplifier was used to measure the whole-cell $\mathrm{Na}^{+}$currents in CCD. After forming a gigaohm seal, the bath solution was changed to either $1 \mathrm{mM}$ or 5 $\mathrm{mM}$ external $\mathrm{K}^{+}$. Measurements were made after currents reached steady state ( 15 minutes after change of bath). ENaC current was assessed as amiloride-inhibitable current at clamp potential of $-60 \mathrm{mV}$. Data were analyzed using the pClamp software system 9.0 (Axon). For inhibitor study experiments, AZD8055 (1 $\mu \mathrm{M})$ or an equal volume of vehicle was added in the bath solution, after which the bath $\left[\mathrm{K}^{+}\right]$was changed to 
either $1 \mathrm{mM}$ or $5 \mathrm{mM}$ in the presence of AZD8055 or vehicle. Once stable current was reached, whole-cell measurements were made at a holding potential of $-60 \mathrm{mV}$.

\section{Cell culture, transfection, and treatment}

mpkCCDc14 (mpkCCD) cells were maintained in modified DMEM/Ham's F12 (1:1) medium (regular medium) as described previously (57).

HEK-293T, HEK-293T WNK1 ${ }^{-/-}$(a gift from Arohan Subramanya, University of Pittsburgh) (39), and HEK-293T SIN1 ${ }^{-/}$(32) cells were grown in DMEM (DME H-21, CCFAA005, UCSF Cell Culture Facility) supplemented with $10 \% \mathrm{FBS}$ and $1 \%$ penicillin and streptomycin. Cells were transfected using polyethylenimine (PEI). For experiments with different $\mathrm{K}^{+}$concentrations, DMEM without $\mathrm{KCl}$ was used. $\mathrm{K}^{+}$-free DMEM was supplemented with $\mathrm{KCl}, \mathrm{NaCl}$, or choline chloride to obtain the desired concentrations of $\mathrm{K}^{+}$ in the media, as indicated in the figure legends.

\section{Measurement of ENaC-dependent $\mathrm{Na}^{+}$transport}

For electrophysiological measurements, mpkCCDc14 cells were seeded on type I collagen-coated filters (Transwell, pore size $0.4 \mu \mathrm{m}$, Corning Costar) until the cell monolayers reached transepithelial resistance greater than 1,000 $\Omega \mathrm{cm}^{2}$. They were then maintained in serum-free plain DMEM for at least 16 hours before treatment with aldosterone ( $1 \mu \mathrm{M}$ for 3 hours) to induce endogenous SGK1 expression. For extracellular $\left[\mathrm{K}^{+}\right]$stimulation/recovery experiments, cells were adapted for at least 2 hours to $1 \mathrm{mM}$ or $3 \mathrm{mM}$ $\left[\mathrm{K}^{+}\right]$. At $t=0$, the medium $\left[\mathrm{K}^{+}\right]$was increased by addition of $\mathrm{KCl}$ or equimolar choline chloride or sodium chloride and incubated for 1 hour prior to measurement of amiloride-sensitive current. Transepithelial resistance and potential difference across the cell monolayer were measured using Millipore Millicell ERS voltohmmeter. The equivalent short-circuit current was calculated using Ohm's law. Amiloride $(10 \mu \mathrm{M})$ was added to the medium on the apical side at the end of the experiments to derive the amiloride-sensitive component of the current. Amiloride almost completely (>98\%) inhibited the total current, indicating its $\mathrm{ENaC}$ dependence. In some experiments, cells were adapted to $5 \mathrm{mM}\left[\mathrm{K}^{+}\right]$and then transferred to media with different $\left[\mathrm{K}^{+}\right]$as specified.

In inhibitor study experiments, the inhibitors AZD8055 ( $1 \mu \mathrm{M}$, apical and basolateral sides), GSK650394 (6 $\mu \mathrm{M}$, apical and basolateral sides), $\mathrm{BaCl}_{2}(100 \mu \mathrm{M}$, basolateral side), VU0134992 (10 $\mu \mathrm{M}$, apical and basolateral sides), or equal volumes of vehicle as the control were added for specified periods of time. Following electrophysiological measurements, cells were harvested and processed for immunoblot analysis.

\section{Immunoblotting}

Cultured cells. To determine protein expression levels, Western blot analysis was performed as previously described (7). Briefly, cells were lysed using lysis buffer containing complete protease inhibitor cocktail and PhoSTOP phosphatase inhibitor. Total protein $(40 \mu \mathrm{g})$ from each cell extract supernatant was electrophoresed in $7.5 \%$ polyacrylamide gels. The blots were then probed with primary antibodies followed with horseradish peroxidase-conjugated (HRP-conjugated) secondary antibodies. Each experiment was repeated more than 3 times. The bands corresponding to p-SGK1 and total SGK1 were quantified using ImageJ software (NIH), as previously described (52).

Kidney lysates. Half kidneys were homogenized in $1 \mathrm{ml}$ lysis buffer using a TissueLyser (Qiagen). The supernatant was aspirated and protein concentrations were measured, electrophoresed, and blotted as further described in supplemental information.

\section{Expression constructs}

Flag-SGK1 and SIN1-V5 were generated as described previously (58). WT WNK1 (residues 1-491) and WNK1 (residues 1-491) (K233M) were gifts from Melanie Cobb (Department of Pharmacology, UT Southwestern Medical School, Dallas, Texas, USA) and Chou-long Huang (Department of Medicine-Nephrology, University of Iowa Health Care, Iowa City, Iowa, USA) (37).

\section{Statistics}

GraphPad Prism and Microsoft Excel were used for data analysis. Comparison between 2 groups was performed by Student's $t$ test. Comparison between more than 2 groups was analyzed by 1-way ANOVA 
with Bonferroni's multiple-comparison post hoc test. Comparison of data collected time dependently was done with 2-way ANOVA with Bonferroni's multiple-comparison post hoc test. The statistical tests used are stated in each figure legend. We presuppose normal/Gaussian distribution of the data but did not test for this, because of the low $n(n=6-8)$ values in our data. Time-dependent data are shown as mean \pm SEM. Time-independent data are shown as bar charts or individual data points in dot plots. Mean \pm SEM are depicted as horizontal lines on top of the individual data point. $P<0.05$ was considered significant and $P$ values are either shown directly in the figures or symbols for $P$ values are explained in figure legends.

\section{Study approval}

Animal experiments were performed in accordance with the Danish legislation on the protection of animals (Dyreforsøgstilsynet license numbers 2013-15-2934-00787 and 2017-15-0201-001166).

\section{Author contributions}

MVS, BS, ISJ, PW, NA, SLS, and WHW conducted the experiments and analyzed data. CEG developed the SIN1-KO cell line. CEG and SLS contributed to scientific discussion. MVS, BS, and DP designed the study. MVS, BS, and DP drafted the manuscript.

\section{Acknowledgments}

This research was supported by grants from the NIH (R01-DK56695 to DP, R01-DK54983 to WHW), the James Hilton Manning and Emma Austin Manning Foundation to DP, and Collaborative Projects between AIAS and the Aarhus University's Research Foundation to ISJ. MVS was cofunded by Aarhus University's Research Foundation and the European Union's 7th Framework Program under grant agreement number 609033. We thank animal caretakers and technicians, particularly Nina Hald Andersen at the Institute of Biomedicine, Aarhus University. Special thanks go to laboratory technician Karen S. Sørensen. We are grateful to Jens Leipziger, Alicia McDonough (USC), and Roger Nicoll (UCSF) for helpful discussions. We thank Priyanka Rashmi and Prasanna K.R. Allu (UCSF) for helpful scientific discussions. We thank Kevan Shokat (UCSF) for providing PP242 and Sujay Kharade and Jerod S. Denton (Vanderbilt University Medical Center) for providing VU0134992. We also thank Arohan R. Subramanya (University of Pittsburgh) for providing WNK1-KO cells and Melanie Cobb and Chou-long Huang for WNK constructs.

Address correspondence to: David Pearce, Genentech Hall, Rm N272C, University of California, San Francisco, 600 16th St., San Francisco, CA 94158. Phone: 415.476.7015; Email: david.pearce@ucsf.edu. Or to: Mads Vaarby Sørensen, Dept. of Biomedicine, Aarhus University, Ole Worms Alle 4, bygn 1160, 8000 Arrhus C, Denmark. Phone: 45.25883666; Email: mvs@biomed.au.dk.

1. Wang WH, Giebisch G. Regulation of potassium (K) handling in the renal collecting duct. Pflugers Arch. 2009;458(1):157-168

2. Frindt G, Palmer LG. $\mathrm{K}^{+}$secretion in the rat kidney: $\mathrm{Na}^{+}$channel-dependent and -independent mechanisms. Am J Physiol Renal Physiol. 2009;297(2):F389-F396.

3. Pearce D, Bhalla V, Funder JW. Aldosterone and mineralocorticoid receptors: renal and extrarenal roles. In: Skorecki K, Chertow GM, Marsden PA, Taal MW, Yu SL, eds. Brenner and Rector's The Kidney. 10th ed. Philadelphia, Pennsylvania, USA: Saunders Elsevier; 2016:303-324.

4. Lang F, Pearce D. Regulation of the epithelial $\mathrm{Na}^{+}$channel by the mTORC2/SGK1 pathway. Nephrol Dial Transplant. 2016;31(2):200-205.

5. Vallon V, et al. Role of Sgk1 in salt and potassium homeostasis. Am J Physiol Regul Integr Comp Physiol. 2005;288(1):R4-10.

6. García-Martínez JM, Alessi DR. mTOR complex 2 (mTORC2) controls hydrophobic motif phosphorylation and activation of serum- and glucocorticoid-induced protein kinase 1 (SGK1). Biochem J. 2008;416(3):375-385.

7. Lu M, et al. mTOR complex-2 activates ENaC by phosphorylating SGK1. J Am Soc Nephrol. 2010;21(5):811-818.

8. Gleason CE, et al. mTORC2 regulates renal tubule sodium uptake by promoting ENaC activity. J Clin Invest. 2015;125(1):117-128

9. Grahammer F, et al. mTORC2 critically regulates renal potassium handling. J Clin Invest. 2016;126(5):1773-1782.

10. Todkar A, et al. Mechanisms of renal control of potassium homeostasis in complete aldosterone deficiency. J Am Soc Nephrol. 2015;26(2):425-438.

11. Young DB, Paulsen AW. Interrelated effects of aldosterone and plasma potassium on potassium excretion. Am J Physiol. 1983;244(1):F28-F34.

12. Sorensen MV, et al. Rapid dephosphorylation of the renal sodium chloride cotransporter in response to oral potassium intake in mice. Kidney Int. 2013;83(5):811-824.

13. McDonough AA, Youn JH. Need to quickly excrete K(+)? Turn off NCC. Kidney Int. 2013;83(5):779-782.

14. Terker AS, et al. Potassium modulates electrolyte balance and blood pressure through effects on distal cell voltage and chloride. Cell Metab. 2015;21(1):39-50. 
15. Subramanya AR, Ellison DH. Distal convoluted tubule. Clin J Am Soc Nephrol. 2014;9(12):2147-2163.

16. Rengarajan S, Lee DH, Oh YT, Delpire E, Youn JH, McDonough AA. Increasing plasma [K+] by intravenous potassium infusion reduces NCC phosphorylation and drives kaliuresis and natriuresis. Am J Physiol Renal Physiol. 2014;306(9):F1059-F1068.

17. Shoda W, et al. Calcineurin inhibitors block sodium-chloride cotransporter dephosphorylation in response to high potassium intake. Kidney Int. 2017;91(2):402-411.

18. Hunter RW, Craigie E, Homer NZ, Mullins JJ, Bailey MA. Acute inhibition of NCC does not activate distal electrogenic Na ${ }^{+}$ reabsorption or kaliuresis. Am J Physiol Renal Physiol. 2014;306(4):F457-F467.

19. Veeneman JM, de Jong PE, Huisman RM, Reijngoud DJ. Re: Adey et al. Reduced synthesis of muscle proteins in chronic renal failure. Am J Physiol Endocrinol Metab 278: E219-E225, 2000. Am J Physiol Endocrinol Metab. 2001;280(1):E197-E198.

20. Jensen IS, Larsen CK, Leipziger J, Sørensen MV. $\mathrm{Na}(+)$ dependence of $\mathrm{K}(+)$-induced natriuresis, kaliuresis and $\mathrm{Na}(+) / \mathrm{Cl}(-)$ cotransporter dephosphorylation. Acta Physiol (Oxf). 2016;218(1):49-61.

21. Tiwari S, Nordquist L, Halagappa VK, Ecelbarger CA. Trafficking of ENaC subunits in response to acute insulin in mouse kidney. Am J Physiol Renal Physiol. 2007;293(1):F178-F185.

22. Frindt G, Palmer LG. $\mathrm{K}^{+}$secretion in the rat kidney: $\mathrm{Na}^{+}$channel-dependent and -independent mechanisms. Am J Physiol Renal Physiol. 2009;297(2):F389-F396.

23. Sun P, Yue P, Wang WH. Angiotensin II stimulates epithelial sodium channels in the cortical collecting duct of the rat kidney. Am J Physiol Renal Physiol. 2012;302(6):F679-F687.

24. Bens M, et al. Corticosteroid-dependent sodium transport in a novel immortalized mouse collecting duct principal cell line. $J$ Am Soc Nephrol. 1999;10(5):923-934.

25. Pearce D, Soundararajan R, Trimpert C, Kashlan OB, Deen PM, Kohan DE. Collecting duct principal cell transport processes and their regulation. Clin J Am Soc Nephrol. 2015;10(1):135-146.

26. Huang DY, et al. Impaired regulation of renal $\mathrm{K}^{+}$elimination in the sgk1-knockout mouse. J Am Soc Nephrol. 2004;15(4):885-891.

27. Sherk AB, et al. Development of a small-molecule serum- and glucocorticoid-regulated kinase-1 antagonist and its evaluation as a prostate cancer therapeutic. Cancer Res. 2008;68(18):7475-7483.

28. Sarbassov DD, et al. Rictor, a novel binding partner of mTOR, defines a rapamycin-insensitive and raptor-independent pathway that regulates the cytoskeleton. Curr Biol. 2004;14(14):1296-1302.

29. Pearce LR, Sommer EM, Sakamoto K, Wullschleger S, Alessi DR. Protor-1 is required for efficient mTORC2-mediated activation of SGK1 in the kidney. Biochem J. 2011;436(1):169-179.

30. Hong F, Larrea MD, Doughty C, Kwiatkowski DJ, Squillace R, Slingerland JM. mTOR-raptor binds and activates SGK1 to regulate p27 phosphorylation. Mol Cell. 2008;30(6):701-711.

31. Hall BA, Kim TY, Skor MN, Conzen SD. Serum and glucocorticoid-regulated kinase 1 (SGK1) activation in breast cancer: requirement for mTORC1 activity associates with ER-alpha expression. Breast Cancer Res Treat. 2012;135(2):469-479.

32. Gleason CE, et al. Phosphorylation at distinct subcellular locations underlies specificity in mTORC2-mediated activation of SGK1 and Akt. J Cell Sci. 2019;132(7):null.

33. Lachheb S, et al. Kir4.1/Kir5.1 channel forms the major $\mathrm{K}^{+}$channel in the basolateral membrane of mouse renal collecting duct principal cells. Am J Physiol Renal Physiol. 2008;294(6):F1398-F1407.

34. Kharade SV, et al. Discovery, characterization, and effects on renal fluid and electrolyte excretion of the Kir4.1 potassium channel pore blocker, VU0134992. Mol Pharmacol. 2018;94(2):926-937.

35. Richardson $\mathrm{C}$, et al. Activation of the thiazide-sensitive $\mathrm{Na}^{+}-\mathrm{Cl}^{-}$cotransporter by the WNK-regulated kinases SPAK and OSR1. J Cell Sci. 2008;121(Pt 5):675-684.

36. Piala AT, Moon TM, Akella R, He H, Cobb MH, Goldsmith EJ. Chloride sensing by WNK1 involves inhibition of autophosphorylation. Sci Signal. 2014;7(324):ra41.

37. Xu BE, Stippec S, Lazrak A, Huang CL, Cobb MH. WNK1 activates SGK1 by a phosphatidylinositol 3-kinase-dependent and non-catalytic mechanism. J Biol Chem. 2005;280(40):34218-34223.

38. Al-Qusairi L, et al. Renal tubular SGK1 deficiency causes impaired $\mathrm{K}^{+}$excretion via loss of regulation of NEDD4-2/WNK1 and ENaC. Am J Physiol Renal Physiol. 2016;311(2):F330-F342.

39. Roy A, et al. Generation of WNK1 knockout cell lines by CRISPR/Cas-mediated genome editing. Am J Physiol Renal Physiol. 2015;308(4):F366-F376.

40. Xu BE, et al. WNK1 activates SGK1 to regulate the epithelial sodium channel. Proc Natl Acad Sci USA. 2005;102(29):10315-10320.

41. Martin RS, Hayslett JP. Role of aldosterone in the mechanism of renal potassium adaptation. Pflugers Arch. 1986;407(1):76-81.

42. Wingo CS, Kokko JP, Jacobson HR. Effects of in vitro aldosterone on the rabbit cortical collecting tubule. Kidney Int. 1985;28(1):51-57

43. Terker AS, Zhang C, Erspamer KJ, Gamba G, Yang CL, Ellison DH. Unique chloride-sensing properties of WNK4 permit the distal nephron to modulate potassium homeostasis. Kidney Int. 2016;89(1):127-134.

44. Debonneville C, et al. Phosphorylation of Nedd4-2 by Sgk1 regulates epithelial $\mathrm{Na}(+)$ channel cell surface expression. $E M B O J$. 2001;20(24):7052-7059.

45. Diakov A, Korbmacher C. A novel pathway of epithelial sodium channel activation involves a serum- and glucocorticoid-inducible kinase consensus motif in the C terminus of the channel's alpha-subunit. J Biol Chem. 2004;279(37):38134-38142.

46. Welling PA. Regulation of renal potassium secretion: molecular mechanisms. Semin Nephrol. 2013;33(3):215-228.

47. Ellison DH, Terker AS, Gamba G. Potassium and its discontents: new insight, new treatments. J Am Soc Nephrol. 2016;27(4):981-989.

48. Penton D, et al. Extracellular K. J Physiol (Lond). 2016;594(21):6319-6331.

49. McDonough AA, Youn JH. Potassium homeostasis: the knowns, the unknowns, and the health benefits. Physiology (Bethesda). 2017;32(2):100-111.

50. Wang WH, Yue P, Sun P, Lin DH. Regulation and function of potassium channels in aldosterone-sensitive distal nephron. Curr Opin Nephrol Hypertens. 2010;19(5):463-470.

51. Boyd-Shiwarski CR, et al. Potassium-regulated distal tubule WNK bodies are kidney-specific WNK1 dependent. Mol Biol Cell. 2018;29(4):499-509. 
52. Soundararajan R, Melters D, Shih IC, Wang J, Pearce D. Epithelial sodium channel regulated by differential composition of a signaling complex. Proc Natl Acad Sci U S A. 2009;106(19):7804-7809.

53. Larsen CK, et al. Hyperaldosteronism after decreased renal $\mathrm{K}^{+}$excretion in KCNMB2 knockout mice. Am J Physiol Renal Physiol. 2016;310(10):F1035-F1046.

54. Frelin C, Barbry P, Vigne P, Chassande O, Cragoe EJ, Lazdunski M. Amiloride and its analogs as tools to inhibit $\mathrm{Na}^{+}$transport via the $\mathrm{Na}^{+}$channel, the $\mathrm{Na}^{+} / \mathrm{H}^{+}$antiport and the $\mathrm{Na}^{+} / \mathrm{Ca}^{2+}$ exchanger. Biochimie. 1988;70(9):1285-1290.

55. Craft J. Eplerenone (Inspra), a new aldosterone antagonist for the treatment of systemic hypertension and heart failure. Proc (Bayl Univ Med Cent). 2004;17(2):217-220.

56. Su XT, Zhang C, Wang L, Gu R, Lin DH, Wang WH. Disruption of KCNJ10 (Kir4.1) stimulates the expression of ENaC in the collecting duct. Am J Physiol Renal Physiol. 2016;310(10):F985-F993.

57. Bhalla V, et al. Serum- and glucocorticoid-regulated kinase 1 regulates ubiquitin ligase neural precursor cell-expressed, developmentally down-regulated protein 4-2 by inducing interaction with 14-3-3. Mol Endocrinol. 2005;19(12):3073-3084.

58. Lu M, Wang J, Ives HE, Pearce D. mSIN1 protein mediates SGK1 protein interaction with mTORC2 protein complex and is required for selective activation of the epithelial sodium channel. J Biol Chem. 2011;286(35):30647-30654. 